\title{
Variations in Chemical
}

Character of Water in the

Englishtown Formation

New Jersey

GEOLOGICAL SURVEY PROFESSIONAL PAPER 498-B

Prepared in cooperation with

New Jersey Division of Water

Policy and Supply

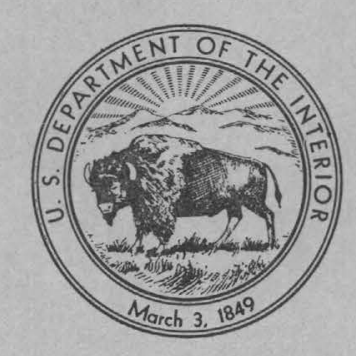





\section{Variations in Chemical}

Character of Water in the

Englishtown Formation

New Jersey

By PAUL R. SEABER

HYDROLOGY OF AQUIFER SYSTEMS

GEOLOGICAL SURVEY PROFESIONAL PAPER 498-B

Prepared in cooperation with

New Jersey Division of Water

Policy and Supply

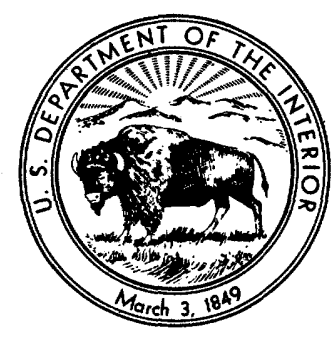

UNITED STATES GOVERNMENT PRINTING OFFICE, WASHINGTON : 1965 


\section{UNITED STATES DEPARTMENT OF THE INTERIOR \\ STEWART L. UDALL, Secretary \\ GEOLOGIGAL SURVEY \\ Thomas B. Nolan, Director}

For sale by the Superintendent of Documents, U.S. Government Printing Office Washington, D.C. 20402 - Price 30 cents (paper cover) 


\section{CONTENTS}

Abstract

Introduction

Purpose and scope.

Previous studies.

Methods of investigation................

Methods of analysis..........................

Expression of results of analyses..............

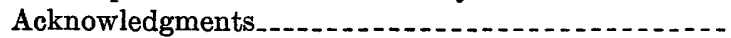

Geology - . . .

Regional setting .

Geology of the Englishtown Formation...........

Occurrence and type locality

Thickness and limits........................

Lithology

Paleontology _...

Origin.-.

Geohydrology

Regional setting

Geohydrology of the Englishtown Formation.-...-

Importance as an aquifer.

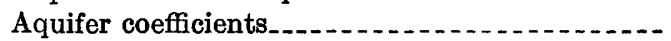

Page
B1
2
2
2
2
8
8
8
9
9
10
10
10
11
12
12
13
13
16
16
16

Geohydrology-Continued

Geohydrology of the Englishtown Formation-Con. Page

Movement of water........................ B16

Pattern before development...............- 16

Pattern after development................ $\quad 17$

Relation of the chemical character of the water to the geology and geohydrology .................... 20

Dissolved solids............... 21

Silica

Temperature............... 21

Iron and $\mathrm{pH}$

Anion hydrochemical facies..................... 23

Bicarbonate and carbonate-1............ 26

Sulfate . . .

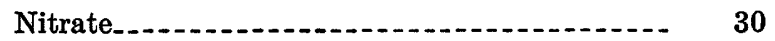

Chloride and fluoride....................... 31

Cation hydrochemical facies.....................-. 31

Calcium and magnesium..................... 31

Sodium and potassium.............. 34

Conclusions_.............. 34

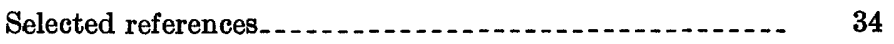

\section{ILLUSTRATIONS}

Frgure 1. Map showing limit of the Englishtown Formation, limit of aquifer use, and wells

2. Generalized cross sections of the Atlantic Coastal Plain of New Jersey, showing pattern of ground-water movement. . . .

3. Maps showing the relation between topography, geology, and ground-water movement 4-5. Hydrochemical maps:

4. Dissolved solids and specific conductance.

5. Temperature, $\mathrm{pH}$, and iron and manganese.

6. Water-analysis diagram

7-9. Hydrochemical maps:

7. Anion and cation facies.

8. Bicarbonate, sulfate, and nitrate.

9. Calcium, magnesium, sodium, and potassium

\section{TABLES}

TABLE 1. Chemical analyses of ground water from wells tapping the Englishtown Formation.

2. Physical properties of sand samples from outcrops of the Englishtown Formation

3. Stratigraphic and geohydrologic units in the northern Atlantic Coastal Plain of New Jersey

4. Classification of hydrochemical facies 


\title{
HYDROLOGY OF AQUIFER SYSTEMS
}

\section{VARIATIONS IN GHEMICAL GHARAGTER OF WATER IN THE ENGLISHTOWN FORMATION, NEW JERSEY}

\author{
By PadL R. Staber
}

\begin{abstract}
This investigation describes the variations in the chemical character of the water in the Englishtown Formation of Late Cretaceous age in the Atlantic Coastal Plain of New Jersey, and demonstrates the application of the concept of hydrochemical mapping to the study and evaluation of water-bearing materials. The Englishtown Formation is an excellent field model because extensive data are available concerning the chemistry of the ground water, the geology, and the geohydrology of the formation.
\end{abstract}

The Englishtown Formation crops out as a distinctive quartzose-sand unit containing a few clay beds in the inner lowland subprovince of the Coastal Plain of New Jersey. The formation strikes $\mathrm{N} .45^{\circ} \mathrm{E}$. and dips 38 feet per mile southeastward. It thins southward and southwestward from a maximum thickness of 140 feet at Sandy Hook Bay and wedges out in exposure in Gloucester County and in the subsurface in Salem, Gloucester, Camden, Burlington, and Ocean Counties. The total areal extent of the formation is approximately 2,000 square miles. In outcrop in the northeast, the formation is a wellsorted fine- to medium-grained nonfossiliferous quartzose sand; mica, lignite, and kaolinitic clays are the dominant accessory minerals. Southward the formation becomes finer grained and fossiliferous, and contains a greater number of intercalated clay beds. In the southern part of the Coastal Plain, the unit grades into undifferentiated fine-grained calcareous, fossiliferous, glauconitic, and micaceous materials. A full suite of heavy minerals characterizes the formation throughout its extent. The outcrop deposits contain kaolinite and varying amounts of illite, and the downdip deposits are characterized by montmorillonite, chlorite, and illite. The Englishtown is the middle unit of the Matawan Group, whose microfauna suggest a Taylor (Campanian) age. The Englishtown in outcrop probably represents a deltaic and beach-complex environment of deposition and the downdip materials a deeper water neritic environment. The dominant source of the sediments was the Appalachian Highlands to the north. Possibly an ancestral Hudson River dumped sediments into an embayment and a nearly uniform lithologic unit was created when the sediments were then reworked by long-shore currents.

Water-level observations indicate that recharge to the Englishtown aquifer occurs by leakage from the overlying sediments under a topographically high landmass 5 to 10 miles downdip from the outcrop. Unlike most other Atlantic Coastal Plain aquifers, the entire outcrop of the Englishtown is a discharge area. Prior to withdrawal of ground water, parts of the adjacent subsurface materials and the Hudson submarine canyon served as discharge areas, but pumping from the Englishtown aquifer has reversed the gradients.
Hydrochemical maps, produced by mapping diagnostic aspects of ground water resulting from a change in the chemical character of the water, indicate a response of chemical processes involving ground water, the lithologic framework, and the pattern of ground-water movement in this framework. The geographic distribution of individual ionic concentrations and ionic ratios can thereby be related to geologic and hydrologic parameters.

Anion hydrochemical facies are mapped by using the ratio of bicarbonate plus carbonate to chloride plus sulfate, in equivalents per million. Bicarbonate is the only anion having a wide range of concentration. The bicarbonate $\left(\mathrm{HCO}_{3}+\mathrm{CO}_{3}\right)$ and the bicarbonate-chloride-sulfate $\left(\mathrm{HCO}_{8}, \mathrm{Cl}+\mathrm{SO}_{4}\right)$ hydrochemical facies are predominant in the ground water. The chloridesulfate $\left(\mathrm{Cl}+\mathrm{SO}_{4}\right)$ and chloride-sulfate-bicarbonate $\left(\mathrm{Cl}+\mathrm{SO}_{4}\right.$, $\mathrm{HCO}_{3}$ ) facies are present in most of the outcrop area because of low concentrations of bicarbonate and not because of large amounts of chloride and sulfate in the water. Saline water, commonly present at depth in other Coastal Plain aquifers, is not present in the Englishtown aquifer.

Cation hydrochemical facies are mapped by using ratios of calcium plus magnesium to sodium plus potassium, in equivalents per million. The concentrations of magnesium and potassium vary only slightly throughout the aquifer. The calcium-magnesium $(\mathrm{Ca}+\mathrm{Mg}$ ) hydrochemical facies results from solution of calcareous material in the overlying formations and forms a belt corresponding to the topographic and piezometric highs. The sodium-potassium $(\mathrm{Na}+\mathrm{K})$ facies occurs at depth and presumably results from ion exchange with montmorillonite. The zone separating the calcium-sodium $(\mathrm{Ca}+\mathrm{Mg}$, $\mathrm{Na}+\mathrm{K})$ hydrochemical facies from the sodium-calcium $(\mathrm{Na}+\mathrm{K}$, $\mathrm{Ca}+\mathrm{Mg}$ ) facies is an "ion exchange front" moving slowly at an indefinite rate east-southeastward, which is the direction of movement of the water within the formation. The present alinement and position of the front is governed more by the piezometric surface that existed prior to pumping from the Englishtown Formation than by the present piezometric surface.

The dissolved-solids content of the ground water, which ranges from 14 to 243 parts per million, is greatest in the areas of the piezometric highs and at depth. Vertical movement of water into the Englishtown aquifer and movement updip within the aquifer produce changes in water temperatures expected from the average geothermal gradient of the Coastal Plain. Sulfate and iron are higher in concentration and the $\mathrm{pH}$ is lower in the outcrop area than at depth. Silica varies irregularly in concentration and distribution.

The chemistry of ground water is responsive to the physical 
environment and lends support to available geologic and hydrologic data. A study of the ground-water chemistry may even suggest concepts for which additional geologic or hydrologic data may not be obtainable by conventional methods of study. Hydrochemical mapping is particularly important in evaluating an aquifer satisfactorily, but it could be equally useful in regional geologic studies concerned with continuity of units or mineralogic differences and similarities.

\section{INTRODUCTION}

\section{PURPOSE AND SCOPE}

This paper describes in detail the variations in the chemical character of the water in the Englishtown Formation of Late Cretaceous age within the Atlantic Coastal Plain of New Jersey. The objective of the paper is to demonstrate the application of quality-ofwater data to the study and evaluation of water-bearing materials.

Water chemistry should be made a useful part of any aquifer study, perhaps even a basic technique of such studies. The areal distribution of the chemical characteristics of the ground water within an aquifer must be related to some physical factor or factors. This study shows (1) that the water chemistry within this particular aquifer is related to the lithologic and topographic framework of the Coastal Plain and to the pattern of ground-water movement within that framework and (2) that the areal distribution of the various chemical characteristics can reveal or substantiate similarities and differences in the geology and ground-water movement within a particular lithologic framework that otherwise may be unnoticed.

The area of investigation lies in the northern part of the Atlantic Coastal Plain of New Jersey (fig. 1) and comprises large parts of Monmouth, Ocean, Burlington, Camden, and Gloucester Counties and minor parts of Mercer, Middlesex, and Salem Counties-about 2,000 square miles. The present extent of aquifer use is an area of about 1,100 square miles. An additional 900 square miles of water-bearing material is not presently (1963) utilized as an aquifer; thus, the chemical characteristics of the ground water in this area must be inferred by extrapolation of the available data.

The report is limited to only one aquifer within the larger hydrologic system of the Atlantic Coastal Plain. However, the limitation of the study allows a more detailed examination of this aquifer and of the applicability of water chemistry to the evaluation of an aquifer.

\section{PREVIOUS STUDIES}

The geology of the Coastal Plain of New Jersey and of the Englishtown Formation has been studied by many workers (see p. B9-B13), but no detailed studies of the geohydrology of the Englishtown have been made previously. Seaber $(1960 ; 1962)$ has described briefly the relation of hydrochemical facies to ground-water flow patterns in the formation.

Results of analyses of water from the Englishtown Formation were published in annual reports of the State Geologist for the years 1854 to 1917 . Thompson (1930) discussed the geology and hydrology of the Englishtown Formation in the vicinity of Asbury Park and compared chemical analyses of ground water from the Englishtown Formation at Belmar with analyses of ground water from the Raritan Formation and from the Wenonah Formation and Mount Laurel Sand at Asbury Park. Barksdale and others (1936) discussed the possibility of salt-water encroachment in the Englishtown Formation in the vicinity of Atlantic City. However, no analyses were given in that report.

Barksdale and others (1943) discussed the geology and hydrology of the Englishtown Formation in Middlesex County and the chemical quality of ground water from this formation as indicated by the results of analyses included in Thompson's (1930) report. Barksdale and others (1958) listed results of seven analyses of water from the Englishtown Formation and briefly discussed the geology, hydrology, and quality of the water in five New Jersey counties adjacent to the lower Delaware River. A report by Seaber (1963) on chloride concentrations of ground water in the New Jersey Coastal Plain contains a summary of the waterbearing properties of the geologic formations, a summary of well data, and a list of chloride determinations of ground-water samples collected between 1923 and 1961.

Reports by Jablonski $(1959 ; 1960)$ on Monmouth County, Rush (1962) on Burlington County, Donski (1963) on Camden County, Hardt (1963) on Gloucester County, and Vecchioli and Palmer (1963) on Mercer County contain well records, logs, chemical analyses, and brief discussions of the geology, hydrology, and water quality of the Englishtown Formation in these counties.

Back $(1960 ; 1961 \mathrm{~b})$ described the hydrochemical facies in the northern part of the Atlantic Coastal Plain and demonstrated broad regional relationships of chemical character of ground water, lithology, topography, and ground-water flow patterns.

\section{METHODS OF INVESTIGATION}

The Englishtown Formation was selected as a suitable field model because of its gross uniform lithology, because data are available concerning its clay minerals, heavy minerals, fossils, chemical analyses of ground water, and water levels, and because wells for obtaining additional water samples are strategically located. The records of wells sampled and the results of the chemical analyses are listed in table 1 . The sampling program 


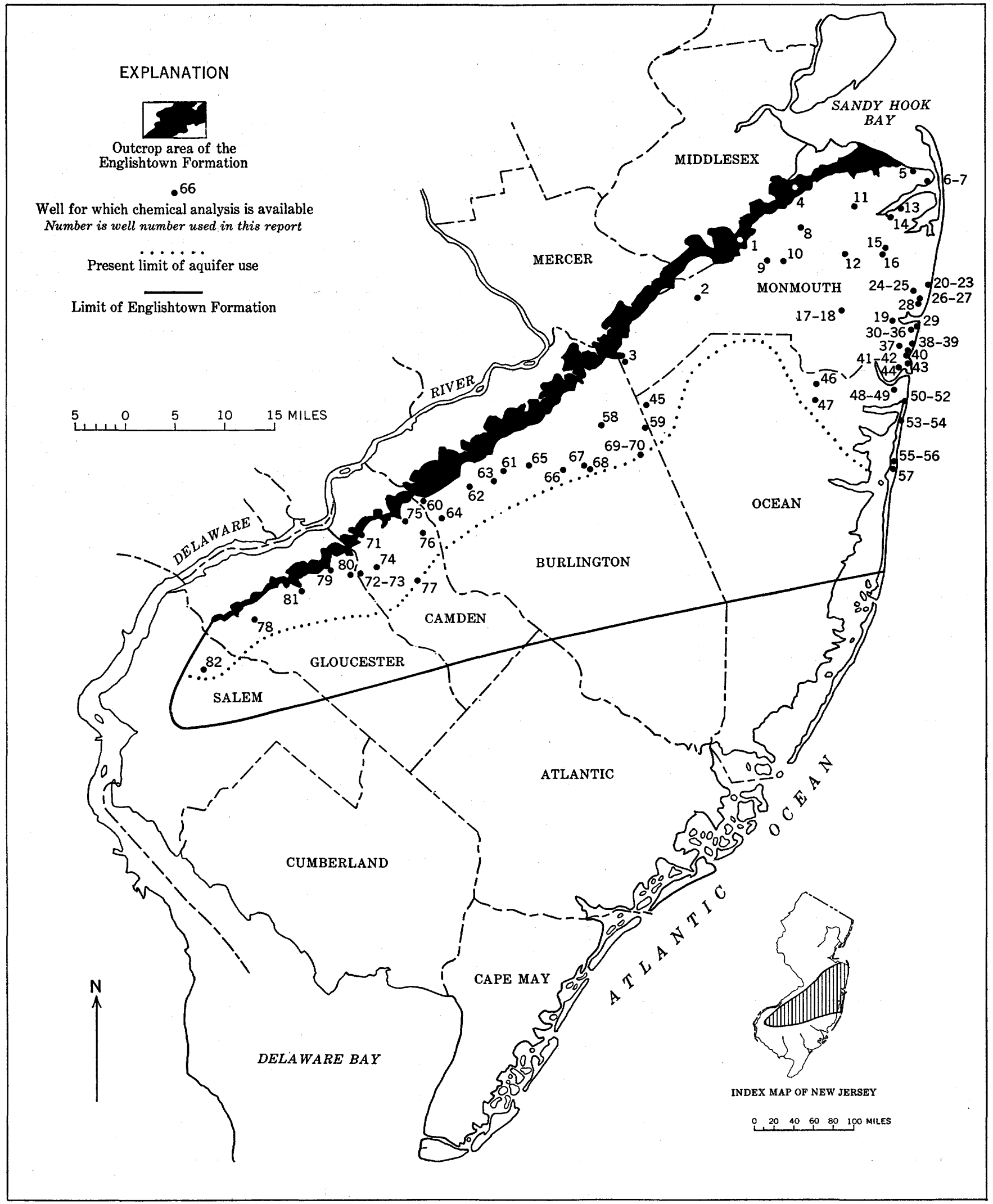

Frouri 1.-Limit of the Bnglishtown Formation, present limit of aquifer use, and wells for which chemical analyses are avallable. 
TABLE 1.-Chemical analyses of ground water from wells tapping the Englishtown Formation

[Source of analyses, U.S. Geological Survey. Use of water: D, domestic; I, industrial; PS, public supply. Results in parts per million, except as indicated]

\begin{tabular}{|c|c|c|c|c|c|c|c|c|c|c|c|c|c|c|c|c|c|c|c|c|c|c|c|c|c|c|}
\hline \multirow[b]{2}{*}{ Location } & \multirow[b]{2}{*}{ 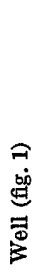 } & \multirow[b]{2}{*}{ Owner } & \multirow[b]{2}{*}{ 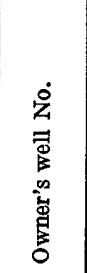 } & \multirow[b]{2}{*}{ 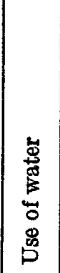 } & \multirow{2}{*}{ 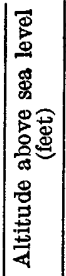 } & \multirow[b]{2}{*}{ 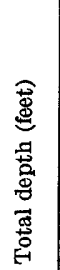 } & \multirow[b]{2}{*}{ 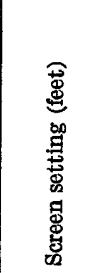 } & \multirow[b]{2}{*}{ 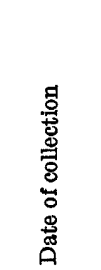 } & \multirow[b]{2}{*}{ 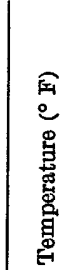 } & \multirow[b]{2}{*}{ 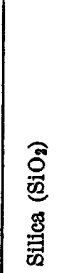 } & \multirow[b]{2}{*}{ 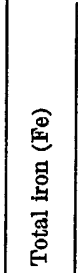 } & \multirow[b]{2}{*}{ 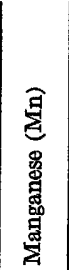 } & \multirow[b]{2}{*}{ 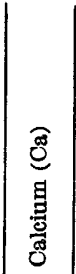 } & \multirow[b]{2}{*}{ 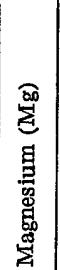 } & \multirow[b]{2}{*}{ 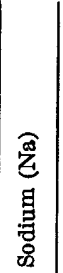 } & \multirow[b]{2}{*}{ 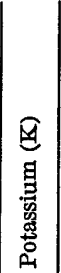 } & \multirow[b]{2}{*}{ 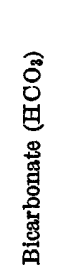 } & & & & & & Dissolve & d solids & 0 & \\
\hline & & & & & & & & & & & & & & & & & & 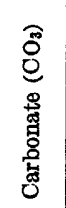 & 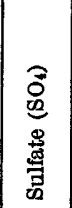 & 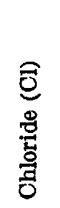 & 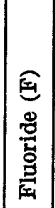 & 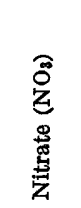 & 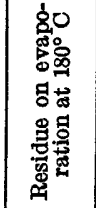 & 喿 & 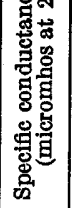 & 畋 \\
\hline Monmouth County & & & & & & & & & & & & & & & & & & & & & & & & & & \\
\hline Clarks Mills. & 1 & $\begin{array}{l}\text { William } \\
\text { Shiermeyer. }\end{array}$ & 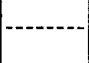 & & 100 & 52 & 47-52 & 7-23-57 & 165 & 5.6 & 11 & 0.00 & 1.7 & 0.3 & 1.0 & 1.4 & & 0 & 8.1 & 2.9 & 0.2 & 0.0 & 14 & 21 & & 4.2 \\
\hline $\begin{array}{l}\text { Do-- } \\
\text { Perrineville.......... }\end{array}$ & $\begin{array}{r}21 \\
2 \\
22\end{array}$ & Abe Kuhl & & $\underset{\mathrm{D}}{\mathrm{D}}$ & $\left|\begin{array}{l}100 \\
200\end{array}\right|$ & $\begin{array}{r}52 \\
160\end{array}$ & $\begin{array}{c}47-52 \\
154-160\end{array}$ & $\begin{array}{l}7-14-61 \\
7-23-57\end{array}$ & $\mid \begin{array}{r}54.1 \\
172 \\
56\end{array}$ & 13 & iii & .00 & 5.1 & 1.1 & 1.0 & 2.1 & $\begin{array}{l}32 \\
13\end{array}$ & $\begin{array}{l}0 \\
0\end{array}$ & 6.9 & 1.9 & . & 3 & 47 & 38 & $\begin{array}{r}82 \\
58\end{array}$ & $\begin{array}{l}6.68 \\
6.4\end{array}$ \\
\hline $\begin{array}{l}\text { Ellisdale-: } \\
\text { Do... }\end{array}$ & $\begin{array}{r}3 \\
23 \\
23\end{array}$ & Atleo Zurlo & & $\begin{array}{l}\mathrm{D} \\
\mathrm{D} \\
\mathrm{D}\end{array}$ & $\left|\begin{array}{l}200 \\
100 \\
100\end{array}\right|$ & $\begin{array}{l}160 \\
109 \\
109\end{array}$ & $\begin{array}{r}154-160 \\
99-109 \\
99-109\end{array}$ & $\begin{array}{l}7-14-61 \\
7-23-57 \\
7-13-61\end{array}$ & $\left|\begin{array}{r}56.9 \\
162 \\
55.2\end{array}\right|$ & 30 & $1 i^{-1}$ & .15 & 22 & 1.2 & 1.1 & 4.2 & $\begin{array}{l}48 \\
59 \\
5\end{array}$ & $\begin{array}{l}\mathbf{0} \\
\mathbf{0}\end{array}$ & 14 & 4.0 & .6 & .4 & iin & $\mathrm{iin} 2$ & $\begin{array}{l}110 \\
114 \\
480\end{array}$ & $\begin{array}{l}6.90 \\
6.9 \\
5.00\end{array}$ \\
\hline Morganville & $\begin{array}{r}4 \\
2\end{array}$ & R. Carroll-_... & & D & $\left|\begin{array}{r}90 \\
95 \\
95\end{array}\right|$ & 44 & $34-38$ & $\begin{array}{r}1-5-01 \\
12-5-54 \\
7-14-61\end{array}$ & $\left|\begin{array}{|c}170.2 \\
170\end{array}\right|$ & 14 & 11 & .06 & 2.1 & 2.7 & 2.8 & 2.6 & $\begin{array}{l}0.0 \\
0 \\
2\end{array}$ & 0 & 33 & 4.4 & $\because 1$ & .5 & 66 & 64 & $\begin{array}{l}425 \\
125 \\
\end{array}$ & 3.9 \\
\hline $\begin{array}{l}\text { Atlantic } \\
\text { Highlands. }\end{array}$ & 5 & $\begin{array}{l}\text { Atantic High } \\
\text { lands Water }\end{array}$ & 2 & PS & $\begin{array}{l}90 \\
20\end{array}$ & 200 & $\begin{array}{c}380-200 \\
180-38\end{array}$ & $4-20-49$ & & $\cdots$ & 4.4 & $\ldots$ & $\cdots$ & $\cdots$ & $\ldots$ & {$[--$} & 65 & 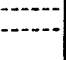 & 12 & 6.0 & $\cdots$ & .0 & $\cdots-1$ & (n) & $\begin{array}{l}148 \\
164\end{array}$ & $\begin{array}{l}4.78 \\
6.5\end{array}$ \\
\hline Do......- & $\begin{array}{r}5 \\
: 5\end{array}$ & De. & 2 & $\underset{P S}{P S}$ & 20 & $\begin{array}{l}200 \\
200\end{array}$ & $\begin{array}{l}180-200 \\
180-200\end{array}$ & $\begin{array}{l}2-28-57 \\
7-17-61\end{array}$ & $\begin{array}{l}56 \\
56,1\end{array}$ & 8.6 & 8.6 & .16 & 14 & 1.4 & 1.7 & 2.1 & 47 & 0 & 7.9 & 2.2 & .1 & .4 & 65 & 62 & 101 & 7.7 \\
\hline $\begin{array}{l}\text { Highlands Air } \\
\text { Force Base. }\end{array}$ & 6 & U.S. Air Force & 1 & PS & $252 \mid$ & 252 & & $4-4-56$ & & 14 & 1.3 & .05 & 44 & 2.1 & 10 & & $\begin{array}{r}94 \\
144\end{array}$ & 0 & 10 & 5.1 & $\because .0$ & (1- & 165 & $-16 \overline{1}$ & $\begin{array}{l}1811 \\
270\end{array}$ & 7.96 \\
\hline Do.. & 6 & -.-.do-.... & 1 & PS & 252 & 252 & & $4-9-56$ & & 14 & .48 & .16 & 35 & 2.7 & 23 & 3 & 146 & $\mathbf{0}$ & 16 & 8.5 & .0 & .1 & 171 & 172 & 288 & 7.3 \\
\hline & $\begin{array}{l}6 \\
7 \\
\end{array}$ & (n) & $\begin{array}{l}1 \\
2\end{array}$ & $\mid \begin{array}{l}\mathrm{PS} \\
\mathrm{PS}\end{array}$ & $\left|\begin{array}{l}252 \\
200\end{array}\right|$ & ${ }_{234}^{252}$ & 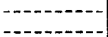 & $\begin{array}{r}11-21-56 \\
2-5-52\end{array}$ & 58 58 & $14^{7.3}$ & $\begin{array}{l}.01 \\
1.8\end{array}$ & .00 & 44 & 3.2 & & 5.9 & 147 & $\begin{array}{l}0 \\
0\end{array}$ & 12 & & $\cdot 2$ & & 4 & 7 & 263 & \\
\hline & $\begin{array}{l}7 \\
7\end{array}$ & - do & $\overline{2}$ & $\mathrm{PS}$ & 200 & $\begin{array}{r}234 \\
{ }_{324}\end{array}$ & (-........... & $4-9-56$ & $\ldots$ & 9.0 & 10.9 & .00 & 36 & & & 8.7 & $\begin{array}{l}147 \\
102\end{array}$ & 0 & & & & 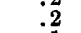 & & 127 & 217 & 7. \\
\hline - & 27 & - do & ${ }_{2}^{2}$ & $\mathrm{PS}$ & $\left|\begin{array}{l}200 \\
200\end{array}\right|$ & $\begin{array}{l}234 \\
234\end{array}$ & - & $\begin{array}{r}11-21-56 \\
7-17-61\end{array}$ & $\begin{array}{l}60 \\
57\end{array}$ & & \begin{tabular}{|l|}
4.0 \\
\end{tabular} & & 47 & 3. & & & $\begin{array}{l}145 \\
162\end{array}$ & 0 & 15 & 3 & .3 & .1 & 167 & 160 & $\begin{array}{l}271 \\
260\end{array}$ & 7.38 \\
\hline$\cdots$ & $\begin{array}{r}8 \\
28\end{array}$ & R. E. Morgan- & & $\underset{\mathrm{D}}{\mathrm{D}}$ & $\left|\begin{array}{l}170 \\
170\end{array}\right|$ & $\begin{array}{l}175 \\
175\end{array}$ & $\begin{array}{l}160-170 \\
160-170\end{array}$ & $\begin{array}{l}7-23-57 \\
7-14-61\end{array}$ & $\begin{array}{c}170 \\
57.9\end{array}$ & 45 & 2.0 & .04 & 32 & 1.7 & 1.2 & 2.2 & $\begin{array}{r}90 \\
106\end{array}$ & 0 & 14 & 3.9 & .5 & .2 & 160 & 145 & $\begin{array}{l}190 \\
203\end{array}$ & $\begin{array}{l}7.2 \\
724\end{array}$ \\
\hline ennent................ & & $\begin{array}{l}\text { S. Martin } \\
\text { Sorensen Ten- } \\
\text { nent Orchards, } \\
\text { Inc. }\end{array}$ & & D & $\left|\begin{array}{|l|}170 \\
130\end{array}\right|$ & & $157-167$ & $7-24-57$ & $\mid \begin{array}{l}1 \\
162\end{array}$ & 18 & .36 & .02 & 17 & $1 . i^{-1}$ & 1.4 & 2.3 & $\begin{array}{r}106 \\
47\end{array}$ & 0 & -10 & 3.2 &.$\overline{4}$ & .2 & 84 & 77 & 111 & 7.3 \\
\hline $\begin{array}{l}\text { Do } \\
\text { Freehold. }\end{array}$ & $\begin{array}{l}29 \\
10\end{array}$ & Freehold Water & old̄ē & $\stackrel{\text { PS }}{\text { PS }}$ & \begin{tabular}{|l|}
130 \\
110
\end{tabular} \mid & $\begin{array}{l}167 \\
200\end{array}$ & $157-167$ & $\begin{array}{l}7-14-61 \\
3-13-57\end{array}$ & $\begin{array}{l}54.9 \\
54\end{array}$ & 15 & .62 & .02 & 42 & 1.6 & 2.3 & 2.5 & $\begin{array}{l}56 \\
98\end{array}$ & 0 & 28 & 4.5 & .1 & .2 & 147 & 145 & $\begin{array}{l}141 \\
234\end{array}$ & $\begin{array}{l}7.32 \\
7.6\end{array}$ \\
\hline $\begin{array}{c}\text { Do-.-. } \\
\text { Everett.-. }\end{array}$ & $\begin{array}{r}210 \\
11\end{array}$ & N. Petruz & old & $\begin{array}{l}\text { PS } \\
\text { D }\end{array}$ & $\begin{array}{l}110 \\
120\end{array}$ & $\begin{array}{l}200 \\
143\end{array}$ & $138-143$ & $\begin{array}{l}7-14-61 \\
7-23-57\end{array}$ & \begin{tabular}{|l|}
53.9 \\
165
\end{tabular} & 7.5 & .14 & .00 & 31 & 6.1 & $1 \overline{8}$ & 2.5 & $\begin{array}{l}106 \\
5\end{array}$ & 0 & 38 & 32 & $\because .2$ & 82 & 243 & 220 & $\begin{array}{l}218 \\
360\end{array}$ & $\begin{array}{l}7.81 \\
6.8\end{array}$ \\
\hline $\begin{array}{l}\text { Do } \\
\text { Colts Neck }\end{array}$ & $\begin{array}{r}211 \\
12\end{array}$ & Atlanti & & $\stackrel{\text { D }}{\text { PS }}$ & $\begin{array}{r}120 \\
86\end{array}$ & $\begin{array}{l}143 \\
280\end{array}$ & $\begin{array}{l}138-143 \\
270-280\end{array}$ & $\begin{array}{l}7-17-61 \\
7-23-57\end{array}$ & $\begin{array}{l}58.1 \\
183\end{array} \mid$ & 1.2 & 30 & (iii & 39 & 1.8 & - 17 & 26 & $\begin{array}{l}156 \\
117\end{array}$ & 0 & 8.4 & 3.5 & [1] & .2 & 132 & 127 & $\begin{array}{l}285 \\
215\end{array}$ & 7.28 \\
\hline Red Bank.. & 13 & $\begin{array}{l}\text { Ship } \\
\text { Red } \mathrm{F}\end{array}$ & 2 & PS & 30 & 281 & $240-284$ & $4-11-50$ & & & 3.4 & & & & & & 133 & & 13 & 5.0 & $\cdots 1$ & .3 & & & 249 & 7.1 \\
\hline$\ldots . .$. & 213 & $\begin{array}{r}\text { Dep } \\
\hdashline-. d o\end{array}$ & 2 & PS & 30 & 281 & $240-284$ & $7-17-61$ & 56.9 & & & & & & & & 2 & & & & & & & & 260 & 7.34 \\
\hline & $\begin{array}{l}14 \\
14\end{array} \mid$ & do & $\begin{array}{l}3 \\
3\end{array}$ & $\begin{array}{l}\text { PS } \\
\text { PS }\end{array}$ & $\begin{array}{l}35 \\
35\end{array}$ & $\begin{array}{l}278 \\
278\end{array}$ & $\begin{array}{l}230-270 \\
230-270\end{array}$ & $\begin{array}{l}4-11-50 \\
2-28-57\end{array}$ & 59 & 17 & $\begin{array}{r}2.7 \\
2.3\end{array}$ & 09 & 43 & 27 & -18] & & $\begin{array}{l}134 \\
131\end{array}$ & 0 & \begin{tabular}{|l}
13 \\
13
\end{tabular} & $\begin{array}{l}4.5 \\
3.8\end{array}$ & {$[-1]$} & .1 & & & 54. & 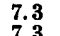 \\
\hline $\begin{array}{l}\text { Fort Mo } \\
\text { Camp }\end{array}$ & 15 & U.S.ArI & A & PS & 45 & 325 & $285-315$ & $8-8-51$ & 54 & 18 & 1.4 & & $\begin{array}{l}70 \\
36\end{array}$ & 4.0 & $10^{\circ}$ & $\begin{array}{l}2.4 \\
3.0\end{array}$ & 131 & 0 & 11 & $\begin{array}{l}5.8 \\
5.5\end{array}$ & $: 1$ & .2 & 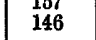 & \begin{tabular}{|l}
148 \\
152
\end{tabular} & 234 & 8.0 \\
\hline & 15 & ....do & A & PS & 45 & 325 & $285-315$ & $4-9-53$ & 58 & $\ldots$ & 1.6 & & 38 & 2.0 & & & & & 9.4 & 8 & & & & & 14 & \\
\hline & $\begin{array}{l}10 \\
16\end{array}$ &..$--d d$ & $\begin{array}{l}\text { B } \\
\text { B }\end{array}$ & $\begin{array}{l}\mathrm{PS} \\
\mathrm{PS}\end{array}$ & $-\alpha$ & $\begin{array}{l}325 \\
325\end{array}$ & & $8-8$ & 58 & 35 & .66 & $\cdots$ & 28 & $\begin{array}{l}2.5 \\
3.5\end{array}$ & 3.2 & 32 & $\begin{array}{l}108 \\
101\end{array}$ & 27 & 14 & 6.0 & .1 & .2 & 188 & 206 & $\begin{array}{l}264 \\
266\end{array}$ & \\
\hline Farmingdale...- & 17 & Farm & 1 & $\begin{array}{l}\text { PS } \\
\text { PS }\end{array}$ & 80 & 480 & $450-480$ & 4-14-49 & & $\cdots$ & $\begin{array}{l}1.0 \\
1.3\end{array}$ & --- & & & & & $\begin{array}{l}121 \\
134\end{array}$ & 0 & 6 & $\begin{array}{l}6.8 \\
3.0\end{array}$ & $-\cdots$ & .12 & $\cdots$ & $\ldots$ & 227 & 7.2 \\
\hline & 17 & & 1 & PS & 80 & 480 & & $9-5$ & & & & & & & & & & & & 3.0 & & & & & & \\
\hline & $\begin{array}{l}17 \\
18\end{array}$ & .....do- & $\begin{array}{l}1 \\
2 \\
\end{array}$ & $\begin{array}{l}\mathrm{P} \\
\mathrm{PS}\end{array}$ & 80 & $\begin{array}{r}480 \\
480\end{array}$ & $450-480$ & $3-1-57$ & 58 & 12 & .88 & .01 & 38 & 3.2 & 2.7 & 3.0 & 128 & 4 & 4.6 & 2.7 & 11 & .2 & 143 & 135 & 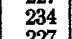 & 8.4 \\
\hline & 218 & do & & $\begin{array}{l}\mathrm{PD} \\
\mathrm{PS}\end{array}$ & 80 & $\begin{array}{l}480 \\
480\end{array}$ & & $\begin{array}{l}9-5-50 \\
7-17-61\end{array}$ & $\begin{array}{l}56 \\
57.5\end{array}$ & & & & & & & & ${ }_{138}^{128}$ & & & & & & & & 227 & 7.84 \\
\hline $\begin{array}{l}\text { Fort } \\
\text { Ca }\end{array}$ & 19 & U.S. Army, Fort & Bldg. & $\mathrm{PS}$ & 90 & 684 & $627-657$ & $8-8-51$ & 54 & 13 & .60 & $\cdots$ & 26 & 5.1 & 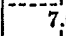 & $0^{0}$ & 98 & 0 & $-\overline{14}$ & 4.0 & {$[\mathrm{i} \mid$} & .4 & (113- & 118 & 189 & 7.6 \\
\hline Aller & 20 & Allenhurst Water & 1 & PS & 10 & 590 & $525-565$ & $8-25-49$ & & - & 1.3 & & 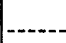 & & & & 88 & & 22 & 1.5 & & .2 & & & 212 & 7.2 \\
\hline$\cdots$ & 21 & Dept. & 2 & PS & 10 & 570 & $525-565$ & $4-11-50$ & & $\cdots$ & 2.6 & & & & & & 94 & & 21 & 2.0 & & .3 & & & 212 & 7.3 \\
\hline & 23 & - & $\begin{array}{l}3 \\
4 \\
\end{array}$ & $\begin{array}{l}\text { PS } \\
\text { PS }\end{array}$ & $\begin{array}{l}10 \\
10\end{array}$ & 570 & 52 & $\begin{array}{l}4-11 \\
3-2\end{array}$ & 64 & & 1.9 & & & & & & 90 & & \begin{tabular}{|l|}
22 \\
36
\end{tabular} & .4 & $\cdots$ & .3 & $\cdots$ & $\ldots$ & 111 & \\
\hline & $\begin{array}{r}23 \\
223\end{array}$ & (n) & $\begin{array}{r}4 \\
4\end{array}$ & PS & 10 & $\begin{array}{l}570 \\
570\end{array}$ & $525-565$ & $3-1-57$ & 62 & 15 & 1.6 & .03 & $-\overline{28-}$ & 4.5 & 3.1 & 4.8 & 88 & 0 & $\mid \begin{array}{l}00 \\
26\end{array}$ & $\begin{array}{l}1.8 \\
1.2\end{array}$ & $\because .1$ & .4 & 125 & 126 & 205 & 0.8 \\
\hline Whitesville....-... & 24 & Monn & $\begin{array}{l}3 \\
1\end{array}$ & PS & & $\begin{array}{l}570 \\
600\end{array}$ & $525-565$ & $\begin{array}{l}7-18-61 \\
8-4-25\end{array}$ & & 10 & .75 & $-\ldots$ & -32 & $\overline{3.2}$ & & & $\begin{array}{r}98 \\
104\end{array}$ & $-\cdots$ & -17 & -3.3 & $\ldots-1$ & Trace & -134 & & 215 & 7.42 \\
\hline Do & 25 & ......do... & 31 & PS & 23 & 566 & 498-566 & $2-54$ & 62 & & .18 & & & & 5. & & 10 & 0 & 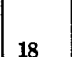 & 28 & 5 & & & & 219 & 7.4 \\
\hline
\end{tabular}




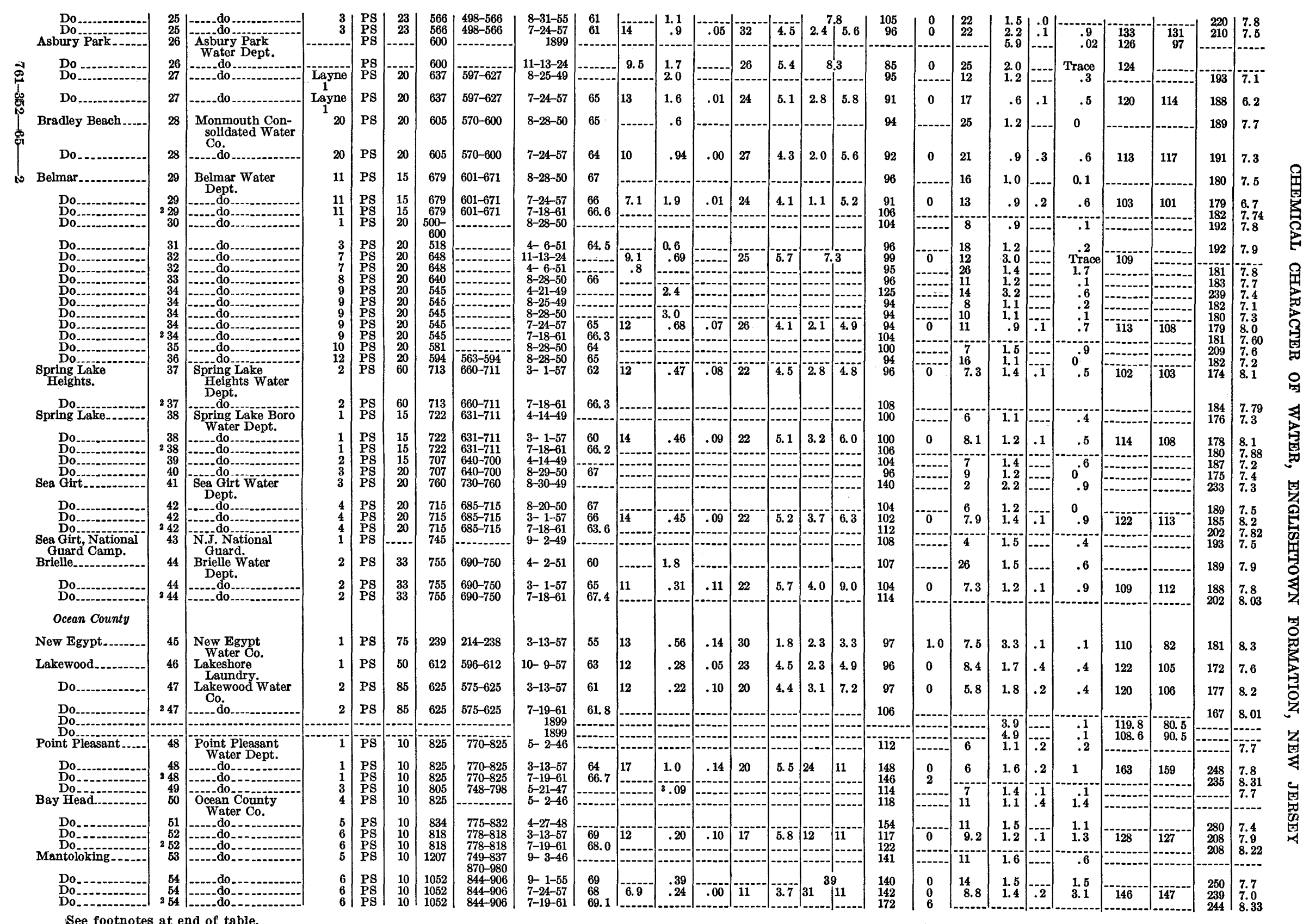




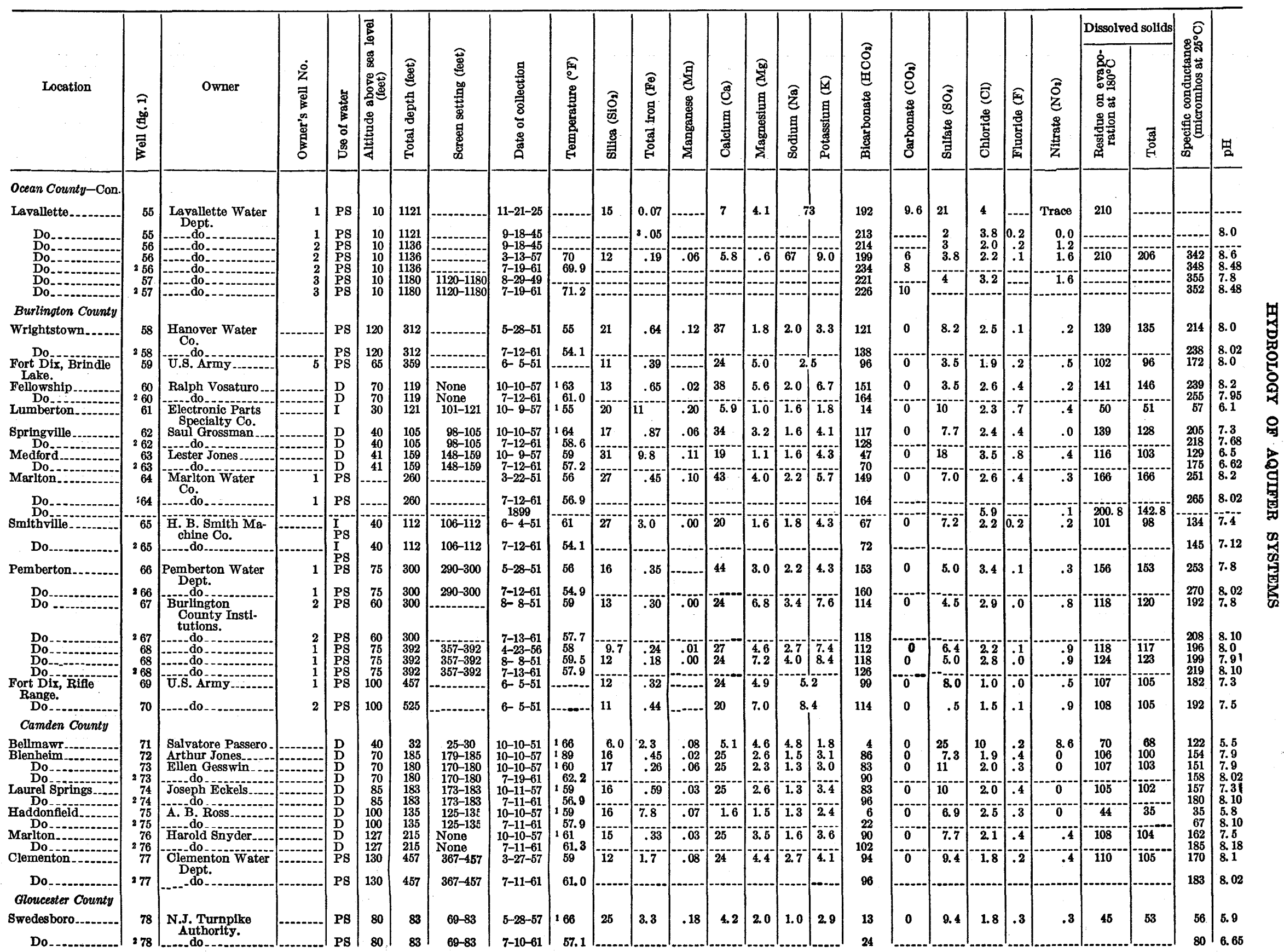




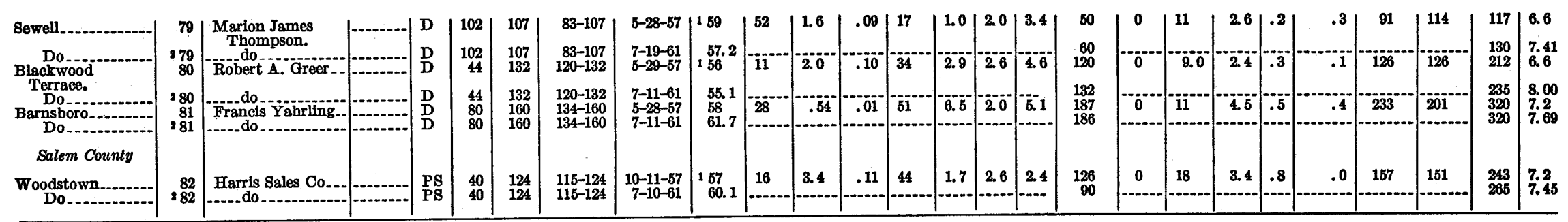

I Tank sample; temperature unreliable. ' In solution at time of analysis. 
was begun in February 1957 and completed in July 1961. The locations of wells sampled are shown in figure 1.

The areal distribution of individual water-quality constituents and the ionic ratios are plotted on maps and contoured. These water-quality maps are compared with the topography, lithology, thickness, and structure of the formation and with generalized groundwater flow patterns. Various water characteristics can then be related to various aspects of the geology and geohydrology, and many conditions of possible hydrologic and geologic significance are thus revealed by the water-quality mapping.

The chemical constituents mapped for this study were chosen because they were responsive to the particular physical environment of the Coastal Plain of New Jersey. However, only those chemical characteristics of water normally determined in a routine analysis were used in the mapping. Thus, many analyses now available for other aquifers could be used for similar studies.

\section{METHODS OF ANALYSIS}

All analytical determinations reported in this investigation were made by the Quality of Water Branch according to the standards of the U.S. Geological Survey. Analyses prior to March 1955 were made in the Washington, D.C., laboratory and subsequent analyses were made in the Philadelphia, Pa., laboratory.

Standard methods for the determination of individual chemical and physical properties of water were described by Rainwater and Thatcher (1960). In most determinations, standard analytical procedures were used and these results agree closely with analyses obtained from other sources. An analysis is considered to be complete if all the major constituents of the water have been determined. Results of all complete analyses used in this report balance within 3 percent; that is, the total equivalents per million (epm) of cations agree with the total equivalents per million of anions to within 3 percent. The 3-percent accuracy insures that there is no significant amount of any constituent in ionic form in the water other than those reported, and also gives a fairly reliable check on the amounts of determined constituents present.

\section{EXPRESSTON OF RESULTS OF ANALYSES}

The results of the analyses are reported in parts per million ( $\mathrm{ppm}$ ) for all constituents. Specific conductance is reported in reciprocal micro-ohms (micromhos) and $\mathrm{pH}$ is reported in standard $\mathrm{pH}$ units. Temperature is reported on the Fahrenheit scale. Temperature, bicarbonate, carbonate, and $\mathrm{pH}$ were measured in the field, and because the field measurements are more representative of conditions in the aquifer than are the laboratory results (Roberson and others, 1963, p. C214C215), they were used in the preparation and interpretation of the maps.

Although the chemical analysis of a ground-water sample merely shows the weights of the constituents in parts per million, the water may be treated as a chemical system of dissolved salts. The constituents in solution are in the form of ions, which carry positive or negative charges. The reported positive ions (cations) are calcium, magnesium, sodium, and potassium. The reported negative ions (anions) are carbonate, bicarbonate, sulfate, chloride, fluoride, and nitrate. Iron, manganese, and silica are considered to be present mainly in the colloidal state as oxides, though they may be partly in the ionic state.

In order to show the results of the analysis in a form in which the reacting capacities of the ions can be readily compared, parts per million are converted to equivalents per million. This is done either by dividing the weight of the substance, in parts per million, by the equivalent, or combining weight, of the ion or by multiplying the parts per million by the reacting weight, which is the reciprocal of the combining weight. Thus, the sum of the reacting values for the cations is approximately equal to the sum of the reacting values for the anions, if the analysis has been made carefully. This further refinement in units of expression may be desirable to help describe the composition of the water and the relationships among the ions in solution.

\section{ACKNOWLEDGMENTS}

The helpful cooperation of well owners who permitted sampling of their wells is gratefully acknowledged, and the results of chemical analyses supplied by the firms of Hungerford \& Terry of Clayton, N.J., and Myers Pump Co. of Ashland, Ohio, are appreciated. The records of wells in table 1 were compiled from data obtained from the New Jersey Bureau of Geology and Topography. Many of the stratigraphic and structural correlations used in determining the subsurface extent of the formation were based partly on studies by other workers.

This investigation was supported by the U.S. Geological Survey in cooperation with the Division of Water Policy and Supply of the New Jersey Department of Conservation and Economic Development. This support was given by the Trenton District under the immediate direction of Allen Sinnott, District Geologist, and under the general direction of Henry C. Barksdale, Branch Area Chief of the Geological Survey, Atlantic Coast Area, and of George R. Shanklin, Chief Engineer and Acting Director of the New Jersey Division of Water Policy and Supply. 
This paper is based upon a dissertation submitted in partial fulfillment of the requirements for a $\mathrm{Ph}$. $\mathrm{D}$. degree at the University of Illinois. The author wishes to thank Professor George B. Maxey, Department of Geology, University of Illinois, under whose immediate supervision the dissertation was prepared, for his guidance and encouragement. The author also appreciates the critical reading of the manuscript and the valuable comments of Professors Don U. Deere, Ralph E. Grim, Harold R. Wanless, and George W. White, who are in the Department of Geology of the university.

\section{GEOLOGY}

\section{REGIONAL SETTING}

The Englishtown Formation occurs in the New Jersey part of the Atlantic Coastal Plain province. This area is largely a region of low relief, consisting of broad plains and gently sloping rounded hills and ridges. The Coastal Plain of New Jersey has been divided by Owens and Minard $(1960$, p. 1) into three physiographic subprovinces: an outer lowland where the elevation rarely exceeds 50 feet above sea level, a broad inner upland where the elevation ranges from 50 to nearly 400 feet, and a narrow inner lowland where the elevation ranges from 50 to 100 feet.

The formations exposed in the Atlantic Coastal Plain in New Jersey are of Late Cretaceous, Tertiary, and Quaternary ages (table 3). The sediments are mostly unconsolidated deposits of gravel, sand, silt, and clay. Most of the gravel occurs in the Quaternary deposits, but fine gravel is associated with quartz sand of the Cretaceous and Tertiary.

The Cretaceous and Tertiary deposits form a wedgeshaped prism that lies unconformably upon the Precambrian, Paleozoic, and Triassic rocks of the Piedmont province. (See fig. 2, p. B14.) In their outcrop area, the Cretaceous and Tertiary formations total approximately 500 to 800 feet in thickness. Their thickness increases downdip, or southeastward, and is shown on the tectonic map of the United States (U.S. Geol. Survey, 1961) as being about 10,000 feet at the extreme tip of southern New Jersey. The sediments extend eastward into a geosyncline having a total thickness in excess of 15,000 feet about 50 to 60 miles east of $\mathrm{New}$ Jersey. Farther eastward, toward the edge of the Continental Shelf, they thin considerably. Deposits of Quaternary age are present over large areas of the Coastal Plain and overlie all the older formations of the area. They vary greatly in thickness and extent.

Many workers have differentiated and classified the sediments of the Atlantic Coastal Plain in New Jersey. The first comprehensive differentiation was made by
Rogers $(1836 ; 1840)$. J. P. Owens and J. P. Minard have done the latest detailed mapping of the Coastal Plain sediments. They have prepared summary tables which differentiate and correlate the sediments according to various workers on Coastal Plain stratigraphy of New Jersey (Owens and Minard, 1960, p. 11-14). No major change, except for refinement of various units within the sequence, has been made since the work of Weller $(1907$, p. 25) on the pre-Miocene stratigraphic sequence and the work of Salisbury and Knapp (1917) on the Quaternary formations. However, Owens and Minard have added considerable insight into the character, distribution, and thickness of the Coastal Plain sediments.

The sediments in the Coastal Plain province have been divided into 22 mappable units, ranging in age from Late Cretaceous to Recent. Beds of Early Cretaceous age (Richards, 1945, p. 894-895) and Late Eocene age (Richards, 1956, p. 84) have been reported in the subsurface along the coast; these beds do not crop out in the State.

The Upper Cretaceous formations strike approximately N. $40^{\circ}-50^{\circ}$ E. and dip gently from 33 to 100 feet per mile southeastward. The strikes and dips of each formation are remarkably uniform, and minor variations are due to slight unconformities. The Tertiary formations strike approximately N. $50^{\circ}-70^{\circ}$ E. and dip 10 to 45 feet per mile southward (Owens and Minard, 1960, p. 5). For the most part, the Quaternary formations consist of flat-lying beds.

The entire Coastal Plain sequence reflects several transgressions and regressions of the sea during the period of deposition. The sediments were deposited under fairly stable shelf conditions and were laid down in continental, transitional, and marine environments. The materials that make up these sediments were derived for the most part from highlands north and west of the present Fall Line. In general, the coarsest grained sands occur in the outcrop parts of the Coastal Plain formations and represent continental, transitional, and shallow-water or near-shore depositional environments. Southeastward toward the Atlantic Coast, the Cretaceous and Tertiary continental and near-shore deposits grade into off-shore marine deposits. The deeper water marine deposits are composed mainly of calcareous clay, silt, and glauconitic sand (Seaber and Vecchioli, 1963, p. B102-B105). Quartzose sand decreases and glauconitic sand increases in abundance seaward. The units are generally thicker seaward and the increase in thickness is accompanied by an increase in the number of beds present.

Weller (1907, p. 180-183) noted that two major faunal assemblages coexisted during the deposition of 
these beds, and he interpreted this fact as reflecting the depths of water in which the sediments accumulated. The forms representing deeper water deposits he designated the Cucullaea suite, and the forms indicating shallow-water or near-shore conditions he designated the Lucina suite. Many of the fossils in the outcrop show evidence of replacement of the original calcareous material by iron oxide.

Groot and Glass (1960) used heavy minerals and clay minerals as indicators of environments of deposition in the Atlantic Coastal Plain of New Jersey. They stated that a full suite of heavy minerals consisting of a great variety of igneous and metamorphic minerals accompanied by the clay minerals illite and montmorillonite is characteristic of the deeper water marine deposits. They also believed that the continental deposits are characterized by a limited or restricted mineral suite of a few stable heavy minerals accompanied by kaolinite and varying amounts of illite. The transitional sediments contain kaolinite, illite, chloritic material, and in places some montmorillonite having a varying heavy-mineral content. Owens and others (1961, p. C317-C319) believed that the clay-sized particles of the Coastal Plain sediments are particularly sensitive indicators of depositional environment, but regarded the differences in mineralogy as the result of a change with time in the type of sediment supplied from the source area.

\section{GEOLOGY OF THE ENGLISHTOWN FORMATION}

\section{OCCURRENCE AND TYPE LOCALTTY}

The Englishtown Formation, of Late Cretaceous age, crops out as a distinctive unit of quartzose sand in the inner lowland subprovince of the Coastal Plain of New Jersey; it forms a narrow belt extending southwestward from Sandy Hook Bay to Gloucester County and is typically a sandy well-drained upland area of low relief. The underlying Woodbury Clay generally forms a broad, poorly drained level area and steep cuesta slope where it is adjacent to the Englishtown outcrop area. The overlying Marshalltown Formation generally underlies poorly drained meadow areas.

The Englishtown is the middle formation of the Matawan Group, which includes in ascending order the Merchantville Formation, Woodbury Clay, Englishtown Formation, Marshalltown Formation, and Wenonah Formation. The Woodbury, Englishtown, and Marshalltown are not recognized as distinct units of the Matawan Group in Delaware, and farther south in Maryland the Matawan is mapped as a formation.

The Englishtown Formation corresponds to a part of the deposits grouped as the laminated sands of the clay marl series by Cook (1868) and as the Hazlet sands by Clark (1898). The formation was termed Columbus bed by Knapp (Salisbury, 1899) and Columbus Sand by Kümmel and Knapp $(1904$, p. 156). The Columbus Sand was named for an occurrence at Columbus, Burlington County. However, the term Columbus was found to be preoccupied by a Devonian formation in Ohio, and the unit was renamed Englishtown Sand by Kümmel (1908, p. 17, footnote). The Englishtown Sand was thus named because the unit is well formed near Englishtown in Monmouth County. The term Englishtown Sand was revised to Englishtown Formation by Owens and Minard (1962) because of the intercalated clays in the outcrop materials and because of the gradation to a clayey facies in the subsurface.

\section{THICKNESS AND LIMITS}

The Englishtown Formation has an average strike of N. $45^{\circ} \mathrm{E}$. and dips approximately 38 feet per mile to the southeast (fig. $3 B$ ). As shown by well logs indicating the top of the formation, the unit at Freehold (well 10) is about 100 feet below land surface, at Brielle (well 44) about 650 feet below land surface, and at Lavallette (well 55) about 1,100 feet below land surface.

The formation in outcrop thins from about 140 feet in northeastern Monmouth County southwestward to Gloucester County where, as shown on the geologic map of New Jersey, it wedges out. On the basis of drillers? logs, thickness variations of 10 to 15 feet appear to be somewhat random throughout most of the subsurface extent of the formation. The formation thins southward and southeastward in the subsurface, and grades laterally from quartzose sand into clayey glauconitic sand. Figure $3 B$ is an isopach map of the Englishtown Formation based on the lithic description of quartzose sand exposed in outcrop. In the southern part of the Coastal Plain of New Jersey, the Matawan Group is composed of a uniform undifferentiated section of very fine grained calcareous, fossiliferous, glauconitic, and micaceous sands, silts, and clays. Other workers have attempted to extend the outcrop formations of the Matawan Group into this subsurface section, apparently on the basis of fossil content and uniform dip. However, inasmuch as this study is concerned primarily with a rock stratigraphic unit, the name Englishtown is restricted to the quartzose sand lithofacies as described in outcrop. This restriction allows limiting the name Englishtown to a distinctive water-bearing unit. In addition, this usage appears to conform more nearly to the Code of Stratigraphic Nomenclature (Am. Comm. on Strat. Nomenclature, 1961) than would an extension of the name Englishtown into the fine-grained glauconitic material of the southern New Jersey Coastal Plain. 
IITHOLOGY

The Englishtown Formation in the northeastern part of its outcrop area is a conspicuous bed of white or tan well-sorted fine- to medium-grained nonfossiliferous quartzose sand. Quartz composes more than 90 percent of the material of the sandy beds. The unit is slightly micaceous and lignitic and contains a few scattered grains of glauconite. There are a few discontinuous beds of dark-gray and light-brown clay interbedded with the sands. Some of the clay beds are rather thick, one such bed of dark lignitic, micaceous clay about 20 feet thick being present in Middlesex County (Barksdale and others, 1943, p. 62). The clay beds are not extensive. Some of the sand beds are cemented by iron oxide that forms semiconsolidated sandstone beds. The ironstone "hardpan" ledges for the most part are very limited in areal extent and less than 2 feet thick. They occur throughout the formation. Some of the cemented layers are conglomeratic and contain pebbles an inch or more in diameter. Tabular cross-stratification is characteristic of the formation.

Owens and Minard (1962) described the formation as well stratified quartz sand in the Columbus quadrangle in Burlington County. Quartz is the dominant mineral and mica, glauconite, and lignite are the conspicuous accessory minerals. The interbedded clay is dark gray to light brown and the clay-sized particles are dominantly quartz, kaolinite, and mica (Owens and others, 1961, p. C319). The conformable contact with the underlying Woodbury Clay in the Columbus quadrangle was described as gradational over a 10-foot interval and as characterized by siderite and quartz concretions. The contact with the overlying Marshalltown Formation was described as sharp, conformable, and marked by an abrupt change from dark-colored sand and clay of the upper part of the Englishtown to the very glauconitic sand of the basal Marshalltown.

Owens and Minard (oral commun., 1961) reported that channel-shaped deposits composed of varying amounts of sand, silt, clay, and fine gravel occur throughout the formation in the Trenton area. They reported no identifiable fossils from the Englishtown in the Columbus quadrangle.

To the southwest, the Englishtown maintains the distinct lithology and mineralogy of a fine- to mediumgrained quartzose sand in outcrop. However, the amount and thickness of the clay layers and the silt content of the sand increase slightly, and the sand becomes finer grained. The results of the size analyses and permeability determinations of sand samples from outcrops of the Englishtown Formation are listed in table 2. These samples have a general uniformity in the statistical measurements of sorting, skewness, and kurtosis. However, the median sand size changes from medium $(0.25-0.50 \mathrm{~mm})$ to fine $(0.125-0.25 \mathrm{~mm})$ from northeast to southwest along the outcrop.

The formation maintains its distinctive character as a lignitic, micaceous quartzose sand in the subsurface. However, the sand becomes increasingly finer grained, glauconitic, pyritic, and fossiliferous at depth. ${ }^{1}$ In summary, the Englishtown Formation in the northeast consists principally of quartzose sand and contains a few clay beds. Southward the sand grades to finer grained sediments that are time correlative with fossiliferous calcareous and glauconitic materials in the southern part of the New Jersey Coastal Plain (Gill and others, 1963).

The Englishtown Formation has a variable heavymineral suite, some sands being epidote-rich and others

1 Gill, H. E., 1956, A stratigraphic analysis of a portion of the Matawan Group : Rutgers Univ. Master's thesis, 167 p.

TABLE 2.-Size analysis and permeability of sand samples from outcrops of the Englishtown Formation [Samples collected from northeast to southwest along the outcrop. All analyses by U.S. Geol. Survey Hydrologic Laboratory, Denver, Colo.]

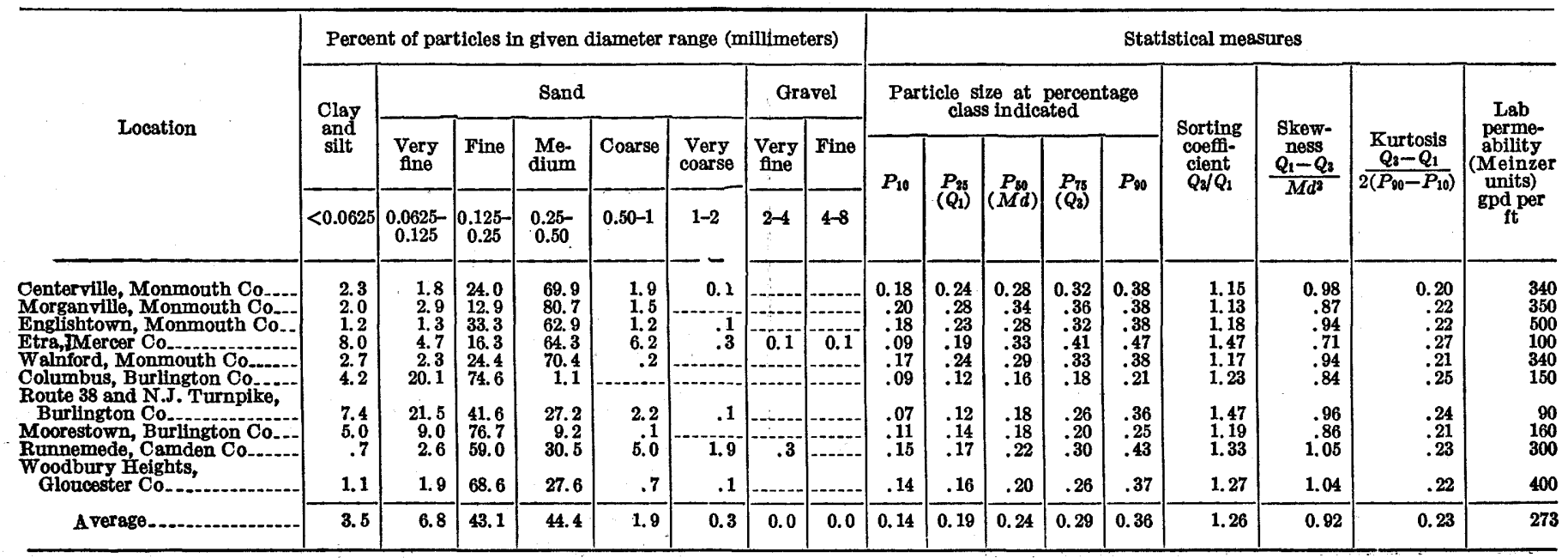


being zircon-rich. Reed (1960) listed heavy minerals from 14 outcrops and 2 wells in the Englishtown Formation. The outcrop sediments contain a fairly uniform heavy-mineral suite, being for the most part zircon-rich and epitode-poor. The outcrop materials contain a wide variety of heavy minerals, including ilmenite, leucoxene, magnetite, staurolite, chloritoid, rutile, garnet, tourmaline, sillimanite, kyanite, andalusite, epidote, monazite, hornblende, and zircon. However, garnet is more abundant in the Marshalltown and Merchantville than in the Englishtown. (See footnote 1, p. B11.) The epidote-rich suites occur at depth both in the southwest and in the northeast. Some of the subsurface materials in Ocean County also contain a zircon-rich suite. In a well at Mantoloking studied by Gill (footnote 1), the material near the contact of the Woodbury was epidote-rich, but near the top of the Englishtown Formation the samples were zircon-rich.

The outcrop deposits of of the Englishtown contain kaolinite with varying amounts of illite, and the downdip deposits are characterized by montmorillonite and illite (Groot and Glass, 1960). The intermediate deposits contain kaolinite, illite, chlorite, and montmorillonite in varying proportions, more kaolinite being toward the outcrop areas and more montmorillonite being at depth in the subsurface.

\section{PAIFONTOLOGY}

H. E. Gill (footnote 1, p. B11) has made a study of the Foraminifera of the Matawan Group, which includes the Englishtown Formation, on the basis of samples from wells at Freehold, Mantua, and Mantoloking and of outcrop samples from Morganville. The samples from Freehold contain no invertebrate microfossils, but contain lignite and seed cases. A part of Gill's thesis (p. 61-64) is quoted herein:

The Englishtown Formation in Morganville, Mantua, and Mantoloking has yielded a combined microfauna of 62 species, representing 31 genera and 11 families. The Mantua and Mantoloking localities have 20 species in common. The Englishtown Sand at Morganville contains a few specimens of Polyphragma and Haplophragmoides indicating an estuarine environment. Thus we can expect no faunal correlation between the outcrop and the downdip sediments.

The microfauna at Mantua is composed of 24 calcareous species, 2 arenaceous, while a larger population is represented at Mantoloking with 51 calcareous and 5 arenaceous species. Twenty-nine of the species are new. Of these 20 are rare or fragmented forms to which no specific identifications can be given. Eleven pelagic species are represented, but their occurrence is marked by a small number of individuals and fragmented specimens.

The Lagenidae and Anomalinidae are the dominant forms both in individuals and species. The Heterohelicidae and Globorotaliidae are fairly well represented by species, but the number of individuals is small in comparison.
Seven species all of which are rare appear to be limited to the Englishtown Formation on present evidence. They are:

Dorothia n. sp. 2

Vaginulina n. sp. 4

Discorbis n. sp. 3

Gümbelina n. sp. 1

Anomalina n. sp. 2

Anomatina n.sp. 3

Planulina n. sp. 2

The faunal evidence indicates a shallow water, sheltered environment, open to the sea, such as a shallow bay. The heavy minerals and mechanical analysis seem to substantiate this conclusion.

Correlation of the 30 species the Englishtown Formation has in common with the Gulf Coast shows only a vague suggestion of Upper Taylor affinities. Lagena hexagona, Lagena sulcata var. semiinterrupta, Pseudouvigerina seligi, and Ceratobulimina cretacea are four Englishtown forms which are restricted to the Navarro on the Gulf Coast. As was mentioned previously, they are probably forms which evolved here. Eleven species occur in the Taylor and Navarro, while only one species is limited to beds of Austin-Taylor age. Fourteen species are long ranging.

In comparing the species which are recurrent in older and younger formations, it is interesting to note that the Englishtown zone marks a reversal of the tendency which was established in the older formations, that of the greatest percentage of recurrent forms usually occurring in the next younger formation.

A substantial percentage of the Woodbury forms persist into the Englishtown zone indicating a continuation of a similar environment.

Sixteen of the Englishtown's 64 species occur in the Merchantville Formation, while 41 occur in the Woodbury Formation and 23 in the Marshalltown Formation.

Richards (1958, p. 23) reported, "The only recognizable macrofossils from the Englishtown Formation are some specimens of Turritella sp., Cardium teniustriata and Lunatia halli from a well at Lavallette. Unidentifiable fragments at Fort Dix, Holmdel, and Mantoloking and from test borings for the New Jersey Turnpike between Runnemede and Woodbury Heights have been recorded (Johnson and Richards, 1952, p. 2155-6)."

\section{ORIGIN}

The Englishtown appears to be of transitional and marine origin. In conjunction with the Woodbury, it represents a single regressive phase of the Late Cretaceous seas. The Englishtown in outcrop probably represents a deltaic and beach-complex environment of deposition. The quartzose sand represents uplift and renewed erosion of the northern Appalachians accompanied by an increase of sediments applied to the northern Coastal Plain. This quartzose sand was then reworked by long-shore currents in a littoral and shallow neritic environment, probably not unlike that along the New Jersey coastal area of the present. The correlative, very fine grained calcareous, fossiliferous, glauconitic, and micaceous sands, silts, and clays found downdip probably represent deeper water marine de- 
posits. The lithelogy and paleontology of the-forma tion indicate oscillating fluvial, back-bay, bay, barrierbeach, and neritic environments of deposition.

The thickness of the formation and shape of the isopachs indicate a source of sediments somewhere to the north of Sandy Hook. The source was possibly an ancestral Hudson River that formed a delta and deposited sediments into an embayment. Other rivers undoubtedly flowed into the embayment from the northwest and contributed sand that was much the same sort but had less total sediment and more clay and silt. The sediments were then reworked by long-shore currents and are now of similar lithology.

The wide extent, uniform thickness, cross-stratification, lithology, statistical measurements, and paleontology of the Englishtown Formation indicate a marine influence. The reported channel deposits and lack of fossils in the outcrop area may indicate fluvial or continental environment. However, it appears that the major part of the formation was deposited in a littoral and shallow neritic environment, and the correlative clayey facies under a deeper water neritic environment.

\section{GEOHYDROLOGY REGIONAL SETTING}

Beneath the land surface of the Coastal Plain of New Jersey, the pore spaces of the unconsolidated rocks contain a great quantity of fresh ground water. This water is vastly greater in quantity than all the fresh water contained at any particular instant in the rivers and lakes on the land surface in New Jersey. The source of virtually all this fresh ground water is precipitation that falls on the surface of the Coastal Plain. This ground water, in general, is of low mineral content and of excellent quality. An approximately equal amount of water contained in the materials underlying the emerged Coastal Plain is saline (Seaber, 1963, p. 3). This saline water occurs in the deeper materials and in a few localized areas in deposits adjacent to saline surface waters.

The fresh ground water is moving slowly through this natural underground reservoir system. It moves from areas of infiltration of rainfall to natural outlets of seepage on the land surface, to the ocean, and to points of artificial diversion.

The quantity in underground storage varies slightly from season to season. It decreases, even with normal precipitation, during the summer and early fall, when the use of water by plants is greatest. It increases during the winter and early spring, when vegetal growth is least.

The Coastal Plain materials differ in the amounts of water they contain and the rates at which this water can move through the formations and into wells. The quantity of ground water in any one place is determined by the size and number of saturated openings in the materials. In the Coastal Plain, virtually all the water occurs in interstices or voids between the grains of the unconsolidated rocks. The size of the rock openings is important. Water held in minute pores is difficult to remove because of the strong capillary attraction between the rock particles and the water, even though the percentage of voids may be fairly high.

Materials such as gravel and the coarse sand contain a considerable amount of large voids, frequently as much as 30 to 35 percent of the rock volume, and transmit and yield the water readily. Material such as clay contains just as much or more void space but, because the voids are smaller, it transmits and yields water very slowly. An intermediate group of materials, in terms of capacity to transmit and yield water, includes finer sand and silt.

The coarser beds in the layers of gravel, sand, silt, and clay which underlie the Coastal Plain are thus very favorable for the storage and movement of ground water; these beds constitute the aquifers of the Coastal Plain, and the finer grained materials constitute the confining beds. Except for the outcrop areas, these more permeable beds form artesian aquifers between confining beds of finer grained material. The aquifers and intervening confining beds of lower permeability do not necessarily conform to the mapped geologic formations of the Coastal Plain (table 3).

Several of the Coastal Plain formations contain aquifers capable of yielding moderate to very large quantities of water to wells. In order of their occurrence from the Fall Line toward the southeast-that is, from oldest to youngest- the aquifers are the permeable sands in the Raritan and Magothy Formations, the Englishtown Formation, the Wenonah Formation and Mount Laurel Sand, the Vincentown Formation, the Kirkwood Formation, and the Cohansey Sand. The overlying irregular and discontinuous veneer of Quaternary sand and gravel serves generally to receive recharge from precipitation, but is generally not thick enough to yield large quantities of water directly to wells.

The aquifers in the Raritan and Magothy Formations are the most heavily pumped and the most important in terms of developed and potential capacity in the Coastal Plain. Eastward these formations occur at increasingly greater depths and it becomes economical to utilize other aquifers. The Englishtown, Wenonah and Mount Laurel, Vincentown, and Kirkwood Formations are capable of yielding moderate supplies of water for industrial and public use, but the ability of these aquifers to store and transmit water is not nearly as great as that of the Raritan and Magothy Formations. 

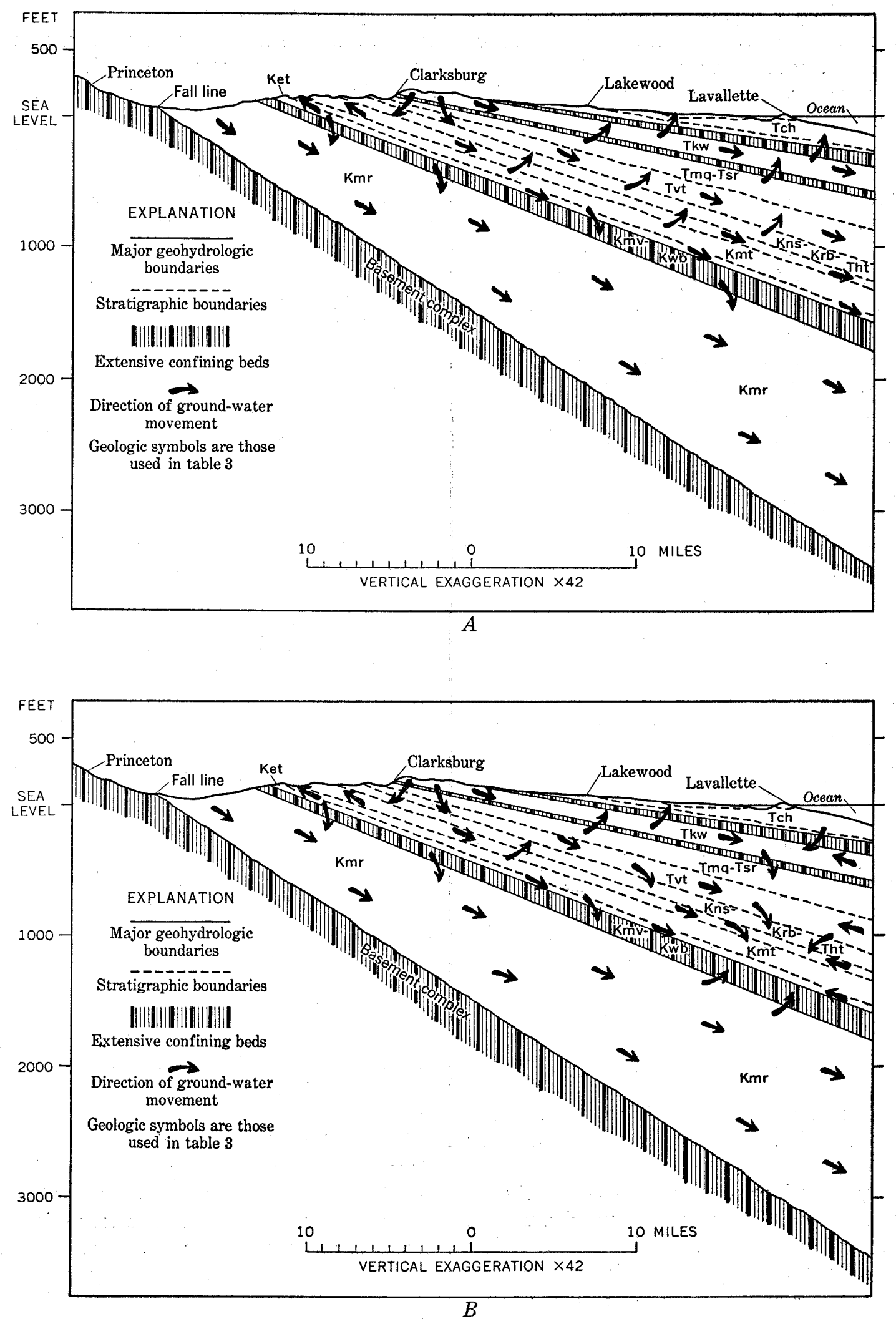

Fradre 2.-The Atlantic Coastal Plain of New Jersey, showing pattern of ground-water movement. 4 , Before withdrawal of water from wells; $B$, after withdrawal of water from wells. 
The Cohansey compares favorably with the Raritan and Magothy in its ability to store and transmit water, but it is essentially undeveloped. The aquifers of Pleistocene age in places compare favorably with the Raritan and Magothy Formations and the Cohansey Sand.

The areally extensive confining beds of the Coastal Plain, in order of their occurrence from oldest to youngest, are the rocks of the basement complex of Triassic and older age, the combined Merchantville and
Woodbury Formations, the diatomaceous clay at the base of the Kirkwood Formation, and the diatomaceous clay unit near the top of the Kirkwood Formation. Other formations contain beds which act as confining layers in local areas, but which are not confining beds throughout their occurrence in the Coastal Plain.

The materials can be divided into several geohydrologic units, as shown in table 3. The generalized pattern of ground-water movement in these units before any great withdrawal of water is compared in figure 2

TABLE 3.-Stratigraphic and geohydrologic units in the northern Atlantic Coastal Plain of New Jersey

\begin{tabular}{|c|c|c|c|c|c|c|c|c|c|}
\hline Bystem & Berles & $\begin{array}{r}\text { Geo } \\
8\end{array}$ & $\begin{array}{l}\text { logic-map } \\
\text { ymbol }\end{array}$ & & Formation & \multicolumn{2}{|c|}{ Geohydrologic units } & $\begin{array}{c}\text { Maximum } \\
\text { reported } \\
\text { thickness } \\
\text { (feet) }\end{array}$ & Lithology \\
\hline \multirow{5}{*}{ Quaternary } & \multirow{2}{*}{ Recent } & & Qal & & Alluvium & \multirow{7}{*}{$\begin{array}{l}\text { Aquifer containing } \\
\text { local confining } \\
\text { beds }\end{array}$} & \multirow{7}{*}{$\begin{array}{l}\text { Recent-Mio- } \\
\text { cene(?) aquifer } \\
\text { system }\end{array}$} & \multirow{2}{*}{80} & Sand, silt, and black mud. \\
\hline & & \multicolumn{2}{|r|}{ Qbs } & \multicolumn{2}{|c|}{ Beach sand and gravel } & & & & $\begin{array}{l}\text { Sand, quartz, light-colored, medium } \\
\text { grained, pebbly. }\end{array}$ \\
\hline & \multirow{3}{*}{ Pleistocene } & \multirow{3}{*}{ Qp } & Qcm & \multicolumn{2}{|c|}{ Cape May Formation } & & & \multirow{3}{*}{200} & \multirow{3}{*}{$\begin{array}{l}\text { Sand, quartz, light-colored, hetero- } \\
\text { geneous, clayey, pebbly, glauconitic. }\end{array}$} \\
\hline & & & Qps & \multicolumn{2}{|c|}{ Pensauken Formation } & & & & \\
\hline & & & Qbt & \multicolumn{2}{|c|}{ Bridgeton Formation } & & & & \\
\hline \multirow{9}{*}{ Tertiary } & Pliocene(?) & & Tbh & \multicolumn{2}{|r|}{ Beacon Hill Gravel } & & & 20 & Gravel, quartz, light-colored, sandy. \\
\hline & $\begin{array}{l}\text { Pliocene(?) and } \\
\text { Miocene(?) }\end{array}$ & & Tch & \multicolumn{2}{|r|}{ Cohansey Sand } & & & 270 & $\begin{array}{l}\text { Sand, quartz, light-colored, medium- } \\
\text { to coarse-grained, pebbly; local clay } \\
\text { beds. }\end{array}$ \\
\hline & \multirow{3}{*}{ Miocene } & \multirow{3}{*}{\multicolumn{2}{|c|}{ Tkw }} & \multirow{3}{*}{\multicolumn{2}{|c|}{ Kirkwood Formation }} & Confining bed & $\begin{array}{l}\text { Great diatom clay } \\
\text { bed }\end{array}$ & \multirow{3}{*}{750} & \multirow{3}{*}{$\begin{array}{l}\text { Sand, quartz, gray to tan, very fine to } \\
\text { medium-grained, micaceous, and } \\
\text { dark-colored diatomaceous clay. }\end{array}$} \\
\hline & & & & & & Aquifer & $\begin{array}{l}\text { Miocene aquifer } \\
\text { system }\end{array}$ & & \\
\hline & & & & & & Confining bed & $\begin{array}{l}\text { Lesser diatom } \\
\text { clay bed }\end{array}$ & & \\
\hline & \multirow{2}{*}{ Eocene } & & Tsr & & Shark River Marl & Confining bed & \multirow{10}{*}{$\begin{array}{l}\text { Eocene-Upper } \\
\text { Cretaceous aqui- } \\
\text { fer system }\end{array}$} & & Sand, quartz and glauconite, gray, \\
\hline & & & Tmq & 을 & $\begin{array}{c}\text { Manasquan } \\
\text { Formation }\end{array}$ & $\begin{array}{l}\text { with local } \\
\text { aquifers }\end{array}$ & & 200 & $\begin{array}{l}\text { grained, clayey, and green silty and } \\
\text { sandy clay. }\end{array}$ \\
\hline & Paleocene & & Trt & 造 & $\begin{array}{l}\text { Vincentown } \\
\text { Formation }\end{array}$ & Aquifer & & 460 & $\begin{array}{l}\text { Sand, quartz, gray and green, fine- to } \\
\text { coarse-grained, glauconitic, and } \\
\text { brown clayey, very fossiliferous; } \\
\text { glauconite and quartz calcarenite. }\end{array}$ \\
\hline & & & Tht & & Hornerstown Sand & \multirow{3}{*}{$\begin{array}{l}\text { Confining bed } \\
\text { with local } \\
\text { aquifers }\end{array}$} & & 100 & $\begin{array}{l}\text { Sand, glauconite, green, medium- to } \\
\text { coarse-grained, clayey. }\end{array}$ \\
\hline \multirow{10}{*}{ Cretaceous } & \multirow{9}{*}{$\begin{array}{c}\text { Upper } \\
\text { Cretaceous }\end{array}$} & & Krb & \multirow{3}{*}{ 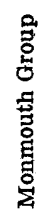 } & Red Bank Sand & & & 185 & $\begin{array}{l}\text { Sand, quartz and glauconite, brown } \\
\text { and gray, fine- to coarse-grained, } \\
\text { clayey, micaceous. }\end{array}$ \\
\hline & & & Kns & & $\begin{array}{l}\text { Navesink } \\
\text { Formation }\end{array}$ & & & 70 & $\begin{array}{l}\text { Sand, glauconite and quartz, green, } \\
\text { black, and brown, medium- to } \\
\text { coarse-grained, clayey. }\end{array}$ \\
\hline & & & & & Mount Laurel Sand & & & & $\begin{array}{l}\text { Sand, quartz, brown and gray, fine- to } \\
\text { coarse-grained, glauconitic. }\end{array}$ \\
\hline & & & $\mathrm{Kmw}$ & & $\begin{array}{l}\text { Wenonah } \\
\text { Formation }\end{array}$ & Aquifer & & 120 & $\begin{array}{l}\text { Sand, quartz, gray and brown, very } \\
\text { fine to fine-grained, glauconitic, } \\
\text { micaceous. }\end{array}$ \\
\hline & & & Kmt & 号 & $\begin{array}{l}\text { Marshalltown } \\
\text { Formation }\end{array}$ & $\begin{array}{l}\text { Confining bed } \\
\text { with local } \\
\text { acquifers }\end{array}$ & & 125 & $\begin{array}{l}\text { Sand, quartz and glauconite, gray and } \\
\text { black, very fine to medium-grained, } \\
\text { very clayey. }\end{array}$ \\
\hline & & & Ket & 范 & $\begin{array}{l}\text { Englishtown } \\
\text { Formation }\end{array}$ & Aquifer & & 160 & $\begin{array}{l}\text { Sand, quartz, } \tan \text { and gray, fine- to } \\
\text { medium-grained; local clay beds. }\end{array}$ \\
\hline & & & Kwb & $\sum_{\Sigma}^{\infty}$ & Woodbury Clay & & & & Clay, gray and black, micaceous. \\
\hline & & & $\mathrm{Kmv}$ & & $\begin{array}{l}\text { Merchantville } \\
\text { Formation }\end{array}$ & Confining bed & $\begin{array}{l}\text { Merchantville } \\
\text { clay bed }\end{array}$ & 255 & $\begin{array}{l}\text { Clay, gray and black, micaceous, } \\
\text { glauconitic, silty; locally very fine } \\
\text { grained quartz and glauconite sand. }\end{array}$ \\
\hline & & & & Mag & thy Formation & Aquifer contain- & Upper Creta- & 95 & $\begin{array}{l}\text { Sand, quartz, light-gray, fine-grained, } \\
\text { and dark-gray lignitic clay. }\end{array}$ \\
\hline & $\begin{array}{l}\text { Lower } \\
\text { Cretaceous }\end{array}$ & & $\mathrm{Kmr}$ & Rari & an Formation & $\begin{array}{l}\text { ing local con- } \\
\text { fining beds }\end{array}$ & $\begin{array}{l}\text { Cretaceous } \\
\text { aquifer system }\end{array}$ & $+2,000$ & $\begin{array}{l}\text { Sand, quartz, light-colored, fine- to } \\
\text { coarse-grained, pebbly, arkosic, and } \\
\text { red, white, and variegated clay. }\end{array}$ \\
\hline & . & $\mathrm{re}-\mathrm{Cr}$ & etaceous & & & Confining bed & Basement complex & & $\begin{array}{l}\text { Precambrian and early Paleozoic } \\
\text { crystalline rocks - metamorphic } \\
\text { schist and gneiss; locally Triassic } \\
\text { basalt, sandstone, and shale. }\end{array}$ \\
\hline
\end{tabular}


to the pattern of the present after large development of ground-water supplies by wells. The generalized ground-water flow patterns are based on original and present-day piezometric maps of the Raritan and Magothy Formations (Barksdale and others, 1958, p. 113-114), the Englishtown Formation, and the Kirkwood Formation (Gill, 1962, p. 101-102), and on a few original and present-day water levels for the Wenonah, Mount Laurel, and Vincentown Formations.

\section{GEOHYDROLOGY OF THE ENGLISHTOWN FORMATION}

\section{IMPORTANCE AS AN AQUIFER}

The Englishtown Formation has been utilized as an aquifer throughout an area of about 1,100 square miles in the Atlantic Coastal Plain of New Jersey (fig. 1). The formation has an areal extent of about 2,000 square miles; hence, about 900 square miles represents a potential additional source of supply. The Englishtown is an important aquifer in Monmouth and Ocean Counties, especially along the Atlantic Coast. The aquifer is less well developed in Burlington, Camden, Gloucester, and Salem Counties to the southwest, owing to a decrease in thickness and the availability of water from other aquifers. In 1957 , about $8.7 \mathrm{mgd}$ (million gallons per day) was pumped from the Englishtown Formation. About $4.2 \mathrm{mgd}$ was pumped in Monmouth County and about $2.8 \mathrm{mgd}$ in Ocean County.

\section{AQUIFER COFFFICIENTS}

An aquifer test conducted May 14 and 15, 1959, at the Lakewood Water Co. (well 47), Lakewood, N.J., gave a transmissibility coefficient of about $10,000 \mathrm{gpd}$ per $\mathrm{ft}$ (gallons per day per foot) and a storage coefficient of $2.7 \times 10^{-4}$ for the $231 / 2$-hour drawdown phase of the test, pumping at a rate of $660 \mathrm{gpm}$ (gallons per minute); the values were about $16,000 \mathrm{gpd}$ per $\mathrm{ft}$ and $2.0 \times 10^{-4}$ for a $5 \frac{1}{2}$-hour recovery phase. The aquifer is 52 feet thick. The permeability values (Meinzer units) were about $300 \mathrm{gpd}$ per sq $\mathrm{ft}$ for the recovery and about $190 \mathrm{gpd}$ per sq $\mathrm{ft}$ for the drawdown. The results from the recovery phase are thought to be more representative of the aquifer characteristics than those from the drawdown phase, owing to an uncertain prepumping trend. This test suggests that the permeability of the aquifer at depth does not vary greatly from that of the outcrop material. (See table 2.) Therefore, an average permeability of $300 \mathrm{gpd}$ per sq $\mathrm{ft}$ seems to be representative of the entire aquifer. Hence, lines of equal transmissibility could be drawn for the aquifer parallel to the isopach intervals shown in figure $3 B$.

\section{MOVEMENT OF WATER}

PATTERN BEFORE DEVELOPMENT

Before any water was withdrawn from the English- town Formation through wells or other works of man, water flowed through the aquifer entirely in response to natural hydraulic gradients. Figure $3 C$ shows the probable nature of the pattern of flow in the aquifer from the recharge areas to points of discharge; it cannot be used to show the exact direction of flow or to estimate quantitative magnitudes of flow, but it does indicate the general direction of flow before any artificial withdrawal of water was made.

The contour data shown in figure $3 C$ are based upon the earliest records of static water levels in each of the wells shown on the map and upon stream elevations where the streams intersect the base and top of the formation in the outcrop area. The data are not, therefore, based upon any simultaneous observations; "but upon observations extending over a period of nearly 30 years. Some of the water levels may have been affected slightly by the pumping of earlier wells. However, all the measurements were made prior to 1910 , and most were made prior to 1900 , before significant withdrawals of ground water from the Englishtown Formation.

Figures $2 A$ and $3 C$ show that the Englishtown Formation did not receive the major part of its recharge from the outcrop area, as formerly believed. Rather, the principal intake areas were several miles downdip and southeast of the outcrop area. Therefore, recharge to the Englishtown in New Jersey occurred mostly by interformational leakage from the overlying Marshalltown Formation. Some recharge resulted from infiltration of precipitation falling on the outcrop area of the Englishtown, but it was eventually discharged into streams or lost to evapotranspiration. A study of original water levels in wells screened in the overlying formations indicates that there was opportunity for vertical leakage downward into the recharge area of the Englishtown from all these formations up to and including at least part of the Kirkwood Formation.

A comparison of the piezometric map with a relief map of the Coastal Plain shows that the two large recharge areas occurred in areas of topographic highs (fig. $3 A$ ). One recharge area lay largely in Monmouth County, the other lay principally in Camden County. The high water levels seem to reflect the overlying topographically high landmass. The two piezometric highs were separated by a piezometric low corresponding to the topographic low in the same area. A 50-foot piezometric contour that extended southeastward in Monmouth County corresponded to the extension of the topographic high centered in northwestern Monmouth County. Perhaps a 50-foot piezometric contour similarly extended southeastward in Gloucester and Camden Counties, but static water levels in these areas are not known. No estimate can be made of the recharge from 
the Marshalltown Formation to the Englishtown Formation because of the variability in lithology and the lack of reliable permeability values for the Marshalltown.

The water moved through the aquifer from the two large recharge areas toward the outcrop and toward the southeast. The Hudson submarine canyon in the Atlantic Ocean north of Sandy Hook Bay was a major discharge area for the large recharge area in Monmouth County. A southern discharge area is not defined at the other end of the system, but movement was probably upward into the overlying formations.

Water was discharged from the Englishtown Formation in the outcrop area, which is crossed by many small streams and a few large ones. The water table was at a higher elevation than the streams, and these streams received ground-water discharge. The amount of ground-water discharge into the streams is not known but is believed to be of considerable magnitude. Barksdale and others (1958, p. 139), using streamflow data, estimated on the basis of $3 / 4$ to $1 \mathrm{mgd}$ for each of the 130 square miles of intake area that the potential recharge is 100 to $130 \mathrm{mgd}$. A large part of this potential recharge resulting from precipitation in the outcrop area was rejected and became stream discharge.

Some water was discharged from the Englishtown Formation into outcrop areas of the overlying formations between the piezometric high and the outcrop area of the Englishtown. This discharge occurred where stream elevations were lower than the piezometric surface of the Englishtown.. Because the permeability of the Englishtown is much greater than that of the Marshalltown Formation, most of the movement was to the outcrop area of the Englishtown, even in the small areas where gradients permitted upward movement of water.

A comparison of the original piezometric surface of the Englishtown Formation with that of the Raritan and Magothy Formations (Barksdale and others, 1958, p. 113) suggests that movement of water was from the Englishtown through the underlying Woodbury Clay and Merchantville Formation to the Magothy and Raritan throughout the Coastal Plain. The combined Merchantville Formation and Woodbury Clay form one of the most effective aquicludes in the Coastal Plain, and the amount of discharge probably was small in relation to the recharge received from the overlying Marshalltown Formation. Because of the variation of lithology in the Merchantville Formation and the lack of reliable permeability data, no quantitative estimates can be made of the discharge from the Englishtown Formation to the Woodbury Clay and Merchantville Formation.
A comparison of the original piezometric surface of the Englishtown Formation with that of the Atlantic City "800-foot" sand aquifer of the Kirkwood Formation (Gill, 1962, p. 101) and with that of the watertable aquifers suggests that movement of water was from the Englishtown to the surface of the Coastal Plain in the topographic low in Burlington County and along the coast in Monmouth and Ocean Counties. The amount of upward movement of water was probably small, but no quantitative estimates can be made.

\section{PATTERN AFTER DEVELOPMENT}

The artificial removal of large quantities of water from the Englishtown Formation has altered the original pattern of movement. Figure $3 D$ shows the probable nature of the flow of water at the end of 1958 . The contours are based upon water-level measurements taken in tate December 1958 and early January 1959. Some of the water levels may have been affected by pumping, but figure $3 D$ is believed to show the general configuration of the piezometric surface of the Englishtown Formation.

A comparison of the original piezometric surface with that of December 1958 shows little difference between the two piezometric surfaces except in the eastern parts of Monmouth and Ocean Counties. The major high-level recharge areas are still several miles downdip from the outcrop area, and the outcrop area and the topographic low in Burlington County still function as a discharge area for the aquifer. In the area along the Atlantic coast, static-water levels in wells screened in the Englishtown Formation have declined greatly as the result of withdrawals of ground water. Moderately heavy pumping has greatly reduced the amount of discharge received by the area off the northeast coast of New Jersey and has diverted the flow to the area of pumpage. The southwest end of the system has not been altered.

In eastern Monmouth and Ocean Counties, the water levels in wells screened in the Englishtown Formation have declined to the point that now they are lower than the water levels of the underlying Magothy and Raritan Formations, of the overlying Kirkwood Formation, and of the water-table aquifer. Hence, the possibility now exists of movement from both the underlying Raritan and Magothy and the overlying Kirkwood to the Englishtown (fig. $2 B$ ). However, because of the relative impermeability of the Merchantville and Woodbury Formations, the amount of water moved from the Raritan and Magothy to the Englishtown is considered to be of very small magnitude. Movement from the overlying aquifers is probably not great either. 

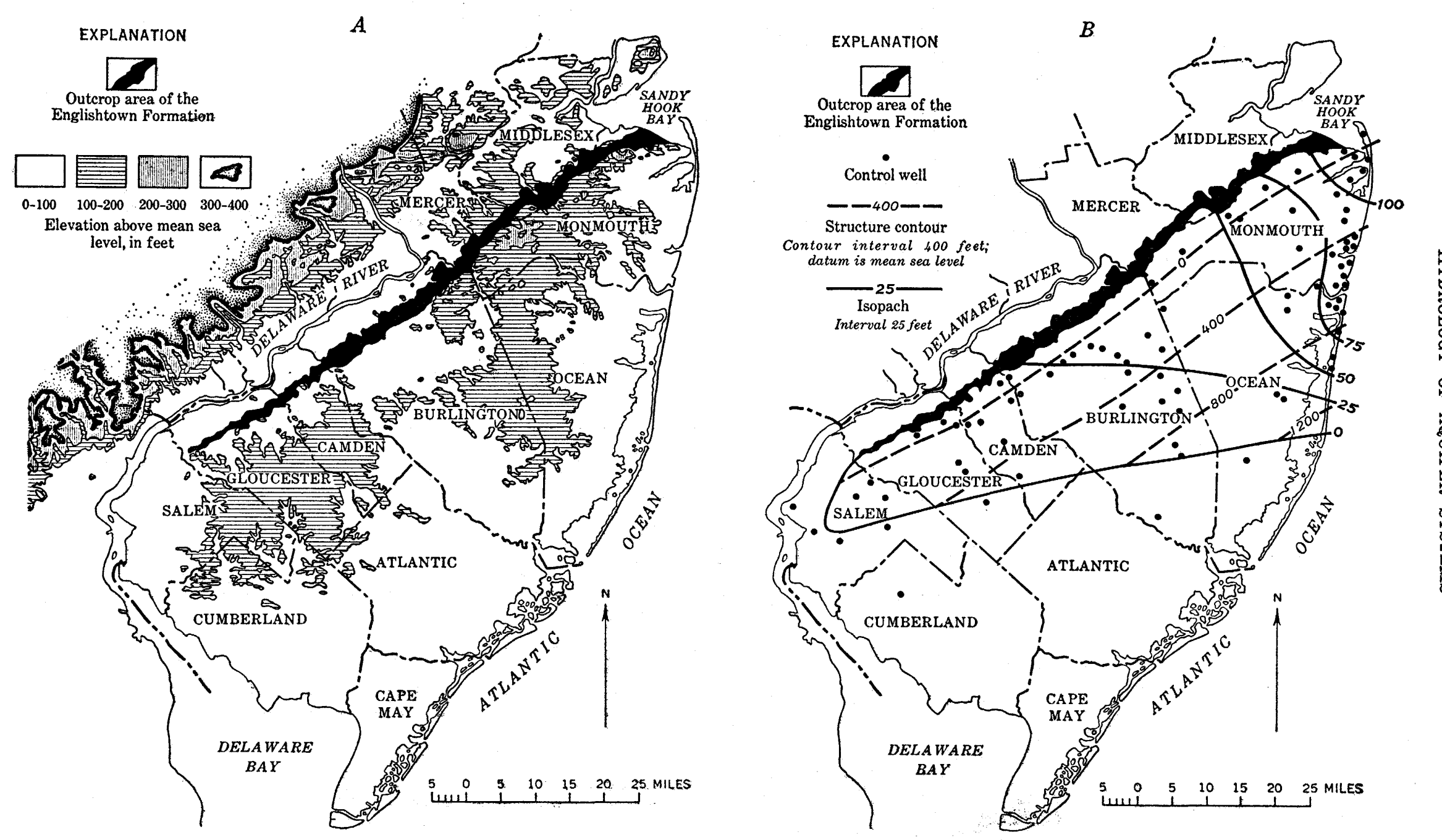

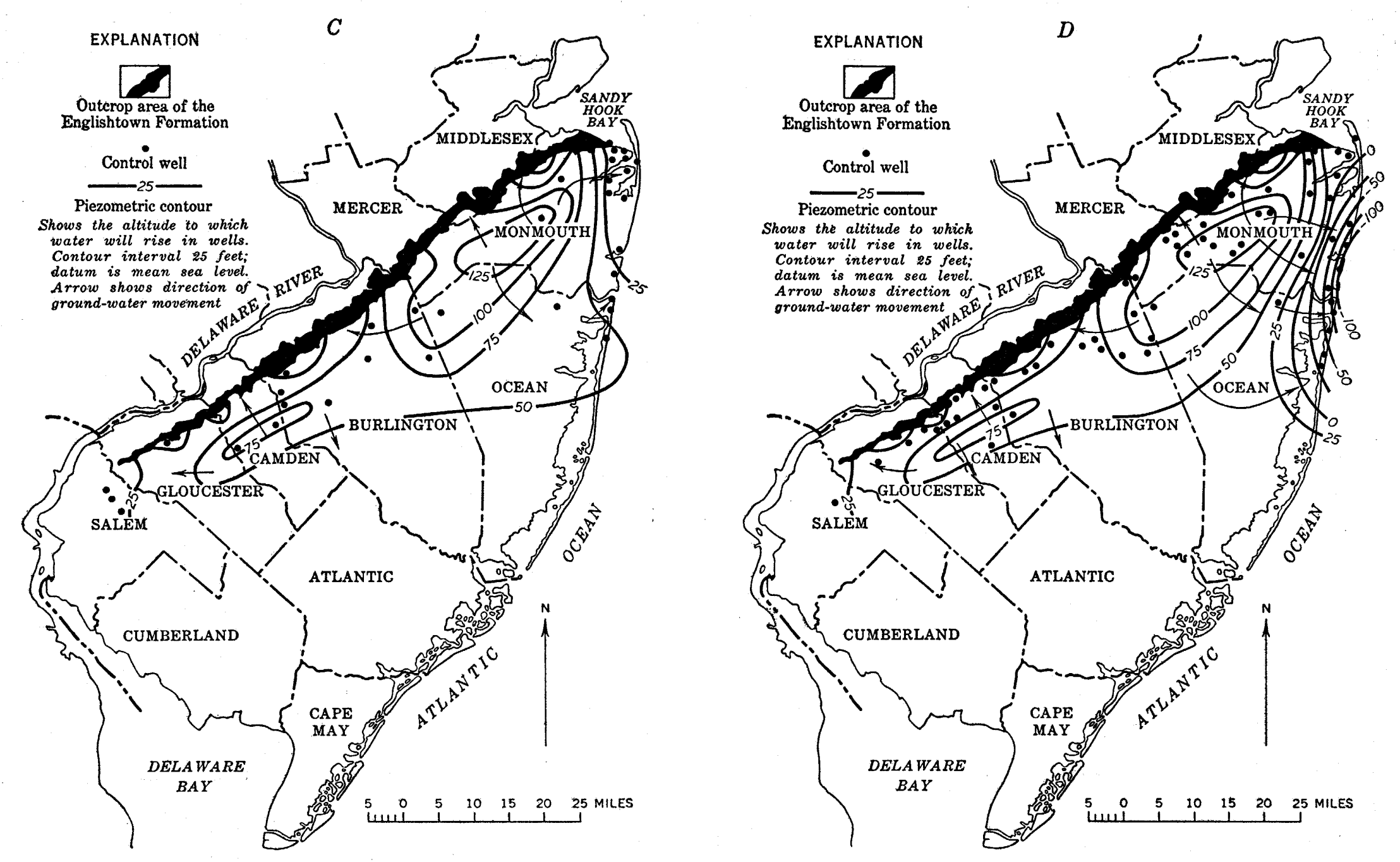

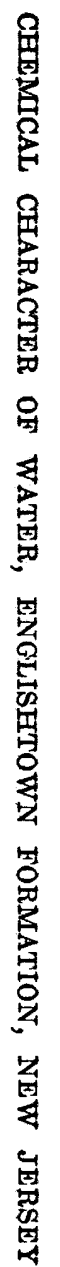

Jrovin 3.-The relation between topography, geology, and ground-water movement. $A$, Generalized topography of the Atlantic Coastal Plain of New Jersey; $B$, structure contoury on top of the finglishtown Formation and isopach map of the formation; $\sigma$, generalized ground-water movement in the Englishtown Formation before 1910; $D$, generallized ground-water movement in the Englishtown Formation in December 1958. 
RELATION OF THE CHEMICAL CHARACTER OF THE WATER TO THE GEOLOGY AND GEOHYDROLOGY

Areal variations in the chemical characteristics of the ground water in the Englishtown Formation are influenced chiefly by the chemical characteristics of precipitation, the mineral composition of the overlying and underlying formations, the mineral composition of of the aquifer, the ground-water flow pattern in the Coastal Plain, and the length of time the water has been in contact with the formations. Water is entering the Englishtown throughout most of its subsurface extent, from either the overlying or the underlying materials; hence, areal variations in the chemistry of the ground water in the aquifer cannot be explained entirely by changes in the mineral composition of the aquifer itself or by length of time required for water to move to different parts of the aquifer. The mineral composition of the overlying and underlying formations and the length of time the water has been in contact with the formations influences the chemistry of the ground water in the Englishtown.

Ground water in the outcrop area of the Englishtown Formation is influenced by the chemical character of precipitation on the outcrop, by the nature of the soil, and by the chemical character of the water that has moved updip from the areas of the piezometric highs in the aquifer. In the areas of the piezometric highs, 5 to 10 miles downdip from the outcrop, the water in the aquifer reflects the chemical character of the water in the overlying formations. The water in the overlying aquifer, which is the combined Wenonah Formation and:Mount Laurel Sand, is similar to the water in the Englishtown in these areas. The water updip from the areas of the piezometric highs is a mixture of water moving updip and water entering the aquifer from the overlying Marshalltown Formation. The water entering the Englishtown in this area has had a shorter "residence time" in the overlying formations than that in the area of the piezometric highs. The water at depth in the Englishtown Formation is influenced by the lithology of the Englishtown, by the chemical character of the water moving downdip from the areas of the piezometric highs, and by the chemical character of the water from the overlying and underlying formations. As a result of heavy pumping from the Englishtown in the coastal area of Monmouth and Ocean Counties, water moves from the overlying and underlying aquifers through the confining beds to the Englishtown. However, the amount of water thus transferred is so small that the chemistry of the water in the Englishtown has not been altered significantly.

The chemical icharacter of the ground water probably does not vary significantly between the top and bottom of the Englishtown Formation, although no analyses were made of water obtained from one well at different depths within the aquifer. However, at Belmar, Monmouth County, wells (29 to 36 ) tap the aquifer at different depths within a small area, and the results of the chemical analyses of water from the different wells are within the limits of analytical error. Analyses of the water from these wells and from wells (72 and 73) at Blenheim, Camden County, indicate that the chemistry of the water does not vary within a small local area of the aquifer. Analyses of water obtained from the same well or wells in the same well field over a period of time, especially water samples from Asbury Park (26 and 27) and Whitesville (24 and 25) in Monmouth County, Lakewood (47) in Ocean County, and Marlton (64) in Burlington . County, indicate no significant change in the chemistry of the water over the sampling period (1899-1961).

The chemical characteristics of the ground water are more uniform where the aquifer has greater thickness. In the northeastern part of the area in Monmouth, Ocean, and Burlington Counties, the chemical character of the water is similar over broader areas than in the southwestern part of the area in Camden, Gloucester, and Salem Counties. Less consistency in the character of the ground water in the southwest is found in the dissolved-solids content, specific conductance, $\mathrm{pH}$, temperature, and bicarbonate, calcium, magnesium, and potassium content. In the coastal area of Ocean County, where the aquifer also thins, rapid changes occur in the temperature and in the sodium, bicarbonate, and nitrate content of the water.

Chemical reactions occur in ground water in the Englishtown Formation when the water comes in contact with different materials, when unlike waters are mixed, or when physical changes occur in the physicalchemical system. As water moves downdip in the aquifer, it comes in contact first with a predominantly kaolinitic clay, then with an illitic and chloritic clay, and finally at depth with a montmorillonitic clay. Water moving through the overlying and underlying aquifers toward the Englishtown passes through a variety of materials, and when it enters the Englishtown it is a mixture of unlike waters. Physical changes occur in the physical-chemical system of the aquifer in a variety of ways. Water in the outcrop areas is in contact with the atmosphere and water at greater depths is under a higher pressure and at a higher temperature.

Changes in the chemical character of the ground water are caused by precipitation, solution, oxidation, reduction, and ion-exchange. Chemical precipitation brings about changes in the iron, manganese, calcium, carbon dioxide, and bicarbonate content of the ground 
water in the Englishtown Formation; the decrease thus produced in these constituents appears to be controlled primarily by $\mathrm{pH}$ and the temperature of the water.

Solution produces an increase in the concentration of all the elements present in the water, along the flow lines in the aquifer. In addition to atmospheric precipitation, a wide variety of minerals could contribute the fairly small amounts of dissolved constituents in the water in the Englishtown Formation. The reaction of ground water with the feldspars and clay minerals, especially those of the expanding-lattice type, and perhaps with some glauconite could contribute the major cations and the silica in the water. The anions result from reactions with various substances.

Oxidation causes some modification of the iron, sulfate, and $\mathrm{pH}$ content of the water, especially in the outcrop areas. Reduction in the presence of anaerobic bacteria may cause the slight decrease of sulfate content of the water at depth in the aquifer. Ion exchange is responsible for the variation in the amounts of the cations in solution. In Ocean County the cation hydrochemical facies of water changes from a $\mathrm{Ca}+\mathrm{Mg}, \mathrm{Na}+\mathrm{K}$ facies to a $\mathrm{Na}+\mathrm{K}, \mathrm{Ca}+\mathrm{Mg}$ facies.

The chemical character of ground water in the aquifer would be modified considerably if subjected to saltwater encroachment. Although the aquifer extends under the Atlantic Ocean and is probably open to salt water in the Hudson submarine canyon, no increase in chloride content of the water from wells has been reported.

The ground water in the outcrop area of the Englishtown Formation along the Camden and Burlington County boundary line contains mineral matter in amounts that are anomalous with those in the rest of the outcrop area. These anomalous concentrations are higher in $\mathrm{pH}$, calcium, magnesium, sodium, potassium, bicarbonate, and dissolved solids and are lower in iron, manganese, and sulfate than are concentrations in the other parts of the outcrop area. This lack of conformity may be related to the steep gradients in the piezometric surface in the formation just a short distance downdip from the outcrop. If water entered the Englishtown from the overlying Marshalltown Formation, it would be discharged shortly from the outcrop into Pennsauken Creek. An alternate explanation is that the Marshalltown is very clayey in the area immediately adjacent to the Englishtown outcrop and, as a result, not much mixing with precipitation occurs. A third explanation would be that the Englishtown Formation in this area contains abundant calcareous material which produces different equilibrium conditions than prevail in other parts of the outcrop area.

\section{DISSOLVED SOLIDS}

The dissolved-solids content of ground water in the Englishtown Formation is greatest in the areas of the piezometric highs and along the coast in Ocean County (fig. 4A). The ground water in the aquifer displays a rather uniform ratio between dissolved solids and conductance except where is contains less than $50 \mathrm{ppm}$ of dissolved solids (fig. $4 B$ ). The conductance multiplied by 0.63 approximates the dissolved-solids content and the dissolved solids multiplied by 1.59 approximates the conductance for most of the water. A decrease in the calcium and bicarbonate content of the water both updip and downdip from the areas of the piezometric highs is the reason for the decrease in dissolved solids. The increase in dissolved solids along the coast in Ocean County is related to increasing concentrations of sodium and bicarbonate.

\section{SIIICA}

Silicates are the most abundant minerals in the Englishtown Formation. Although quartz is the major mineral of the formation, most of the silica present in the water is probably derived from the decomposition of silicate minerals other than quartz. The silica content of the ground water ranges from 5.6 to $52 \mathrm{ppm}$, but no particular spatial distribution of the silica occurs.

\section{TEMPERATURE}

The temperature of the ground water in the Englishtown Formation is a function of the mean annual air temperature, the geothermal gradient, and the direction of ground-water movement (fig. $5 A$ ). The mean annual air temperature (1931-55) for the Coastal Plain of New Jersey is $53.9^{\circ} \mathrm{F}$. The average geothermal gradient for a large number of wells in the Coastal Plain of New Jersey is $1^{\circ} \mathrm{F}$ increase in temperature for every 68 feet of depth, or $1^{\circ} \mathrm{C}$ increase for every 112 feet of depth. Except for the influence of groundwater movement, or if ground-water movement were directly downdip in all the formations, the temperature of the ground water would be directly related to depth, that is, the geothermal gradient and the isotherms would parallel the structure contours of the formations. Vertical recharge to the Englishtown from the overlying formations and movement of water updip in the aquifer along the Atlantic coast produce changes in this generalized isothermal pattern.

In the area of the northern piezometric high, the temperature of the ground water from a flowing well (10) 200 feet deep is identical to the mean annual air temperature $\left(53.9^{\circ} \mathrm{F}\right)$. If the water temperature at a depth of 200 feet in this area were strictly in accordance with the geothermal gradient for the Coastal 

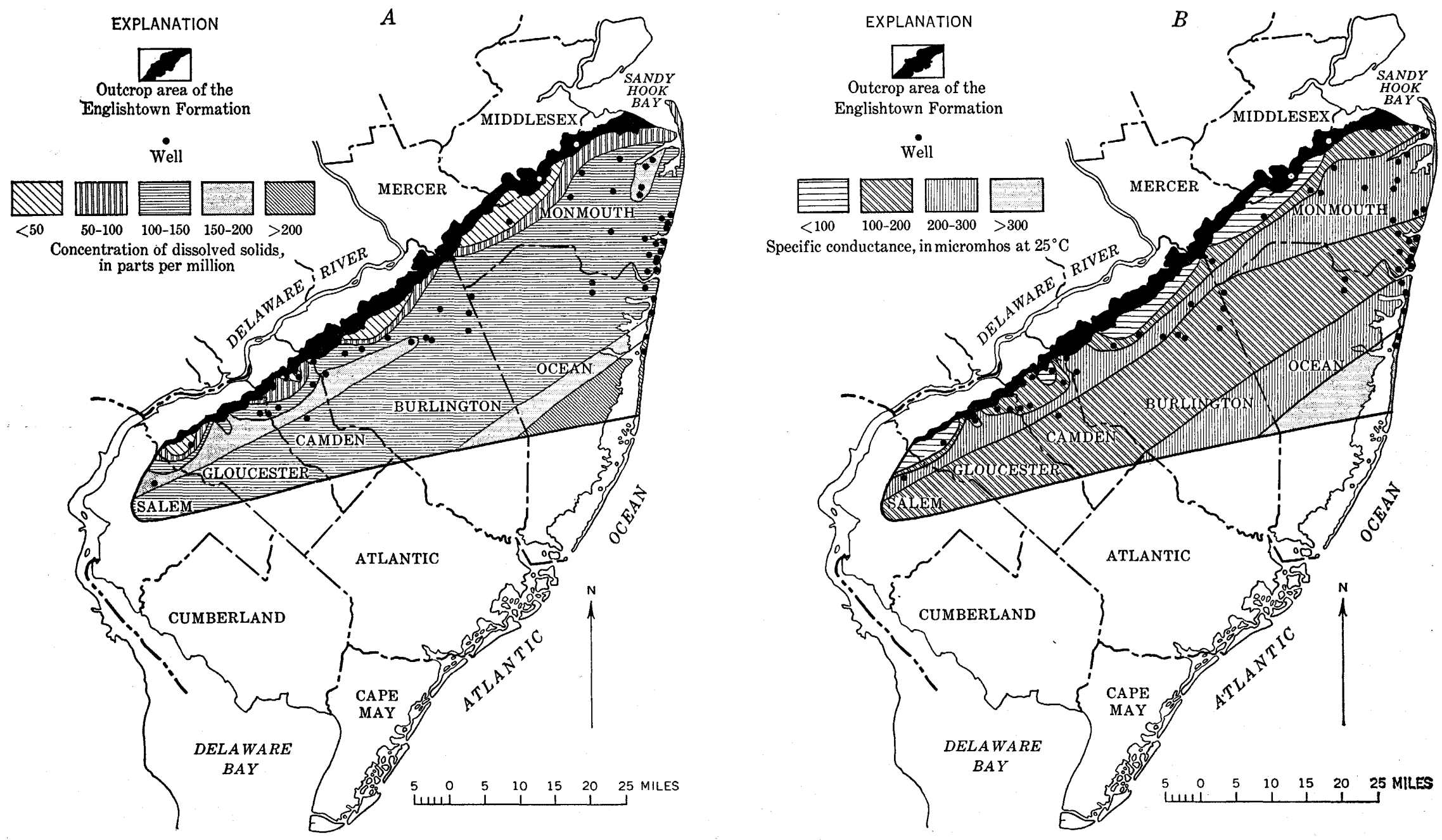

FraUni 4.-Distribution of $(A)$ dissolved solids and $(B)$ specific conductance of ground water in the Englishtown Formation. 
Plain, the temperature of the water would be approximately $57^{\circ} \mathrm{F}$. Obviously, the water temperature in the aquifer has been influenced by the temperature of the water moving downward from the surface.

Water moves southeastward approximately downdip in northern Ocean County and then moves northeastward into Monmouth County. The temperature of the water in the aquifer along the shore in southeastern Monmouth County is therefore high. The isotherms that practically parallel the structure contours in central Monmouth County and northwestern Ocean County are thus deflected northward along the coast in Monmouth County.

The temperature of the water in Burlington County in the piezometric low reflects the temperature of the water entering the aquifer in the piezometric highs. A flowing well (58) 312 feet deep in this area yields water with a temperature only $0.2^{\circ} \mathrm{F}$ higher than the mean annual air temperature.

The temperature of the ground water in Camden, Gloucester, and Salem Counties is $1^{\circ}$ to $2^{\circ} \mathrm{F}$ higher than that at similar depths in Monmouth and Burlington Counties, though it exhibits the same general pattern. The higher temperatures can be explained by the slightly higher mean annual air temperatures in this region. The area along the Camden and Burlington County boundary line has ground water that is higher in temperature than that of other areas at similar depths.

\section{IRON AND pH}

The water in the outcrop area and for a few miles downdip from most of the outcrop area has a $\mathrm{pH}$ of 7.0 or less. In general, the $\mathrm{pH}$ of the water in the aquifer increases gradually with depth (fig. $5 B$ ). The $\mathrm{pH}$ of the ground water in the Englishtown Formation appears to be controlled by the carbon dioxide-bicarbonate buffering system common to most potable ground water. The changes in $\mathrm{pH}$ parallel changes in the bicarbonate and carbonate content of the ground water, a higher $\mathrm{pH}$ occurring in areas of increased bicarbonate and carbonate content. The areas where the water has a $\mathrm{pH}$ of less than 7.0 are those where little or no calcium carbonate is present in the aquifer materials. Changes in $\mathrm{pH}$ are related to the iron content of the water. The areas where the $\mathrm{pH}$ is less than 7.0 yield water with an iron content greater than $5.0 \mathrm{ppm}$; those areas where the $\mathrm{pH}$ is greater than 8.3 yield water with an iron content of less than $0.03 \mathrm{ppm}$.

The ground water in the outcrop area and in the area immediately adjacent to it is everywhere high in iron and manganese, except in the area along the Camden and Burlington County boundary line. The source of the iron is probably the various iron-bearing minerals present in the formation. The manganese content of the ground water is uniformly low throughout the aquifer. In general, the iron content of the ground water decreases with depth of the aquifer (fig. $5 C$ ). There is a high iron concentration in the outcrop area and a low iron concentration at depth. The decrease in iron content probably represents either the precipitation of iron, as iron carbonate or as iron sulfide, or the lack of solution of iron resulting from $\mathrm{pH}$ changes.

\section{ANION HYDROCHEMICAL FACIES}

A hydrochemical facies may be thought of as a diagnostic chemical aspect of ground water indicative of the proportions of the cations and anions (Seaber, 1962 , p. B124). Variations in the proportions of cations and anions reflect environmental effects and can be used as diagnostic indicators of hydrochemical relations.

The following terms, as used by Back (1961, p. 381), designate particular anion hydrochemical facies: The bicarbonate $\left(\mathrm{HCO}_{3}+\mathrm{CO}_{3}\right)$ facies occurs where the bicarbonate plus carbonate exceeds 90 percent of the total anions (on the basis of equivalents per million, not parts per million); the bicarbonate-chloride-sulfate $\left(\mathrm{HCO}_{3}, \mathrm{Cl}+\mathrm{SO}_{4}\right)$ facies indicates that bicarbonate is less than 90 percent, but greater than 50 percent, and the content of the other anions exceeds 10 percent and is less than 50 percent of the total anions; the chloridesulfate-bicarbonate $\left(\mathrm{Cl}+\mathrm{SO}_{4}, \mathrm{HCO}_{3}\right)$ facies occurs where the bicarbonate plus carbonate is less than 50 percent but more than 10 percent of the anions; the chloride-sulfate $\left(\mathrm{Cl}+\mathrm{SO}_{4}\right)$ facies occurs where the chloride plus sulfate content exceeds 90 percent of the total anions. The fluoride and nitrate content of the water in the Englishtown Formation is negligible, but the amounts present are added to the chloride and sulfate content of the water in determining the anion facies.

The classification of the hydrochemical facies used in this report is shown in table 4 and figure 6.

TABLE 4.-Classification of hydrochemical facies

[Percentage of constituents, in equivalents per million. Modified from Back (1961b,

\begin{tabular}{|c|c|c|}
\hline Anion facies: & $\underline{\mathrm{HCO}_{3}+\mathrm{CO}_{3}}$ & $\mathrm{Cl}+\mathrm{SO}_{4}{ }^{1}$ \\
\hline $\begin{array}{l}\mathrm{HCO}_{3}+\mathrm{CO}_{3} \\
\mathrm{HCO}, \mathrm{Cl}+\mathrm{SO}_{4} \\
\mathrm{Cl}+\mathrm{SO}_{4}, \mathrm{HCO} \\
\mathrm{Cl}+\mathrm{SO}_{4} \\
\text { ation facies: }\end{array}$ & $\begin{array}{r}90-100 \\
50-<90 \\
10-<50 \\
0-<10 \\
\mathrm{Ca}+\mathrm{Mg}\end{array}$ & $\begin{aligned} 0-<10 \\
10-<50 \\
50-<90 \\
90-100 \\
\mathrm{Na}+\mathrm{K}\end{aligned}$ \\
\hline $\begin{array}{l}\mathrm{Ca}+\mathrm{Mg} \\
\mathrm{Ca}+\mathrm{Mg}, \mathrm{Na}+\mathrm{K} \\
\mathrm{Na}+\mathbf{K}, \mathrm{Ca}+\mathrm{Mg} \\
\mathrm{Na}+\mathbf{K}\end{array}$ & $\begin{array}{r}90-100 \\
50-<90 \\
10-<50 \\
0-<10\end{array}$ & $\begin{array}{r}0-<10 \\
10-<50 \\
50-<90 \\
90-100\end{array}$ \\
\hline
\end{tabular}

1 May include some $\mathrm{NO}_{3}$ and $\mathrm{F}$ 

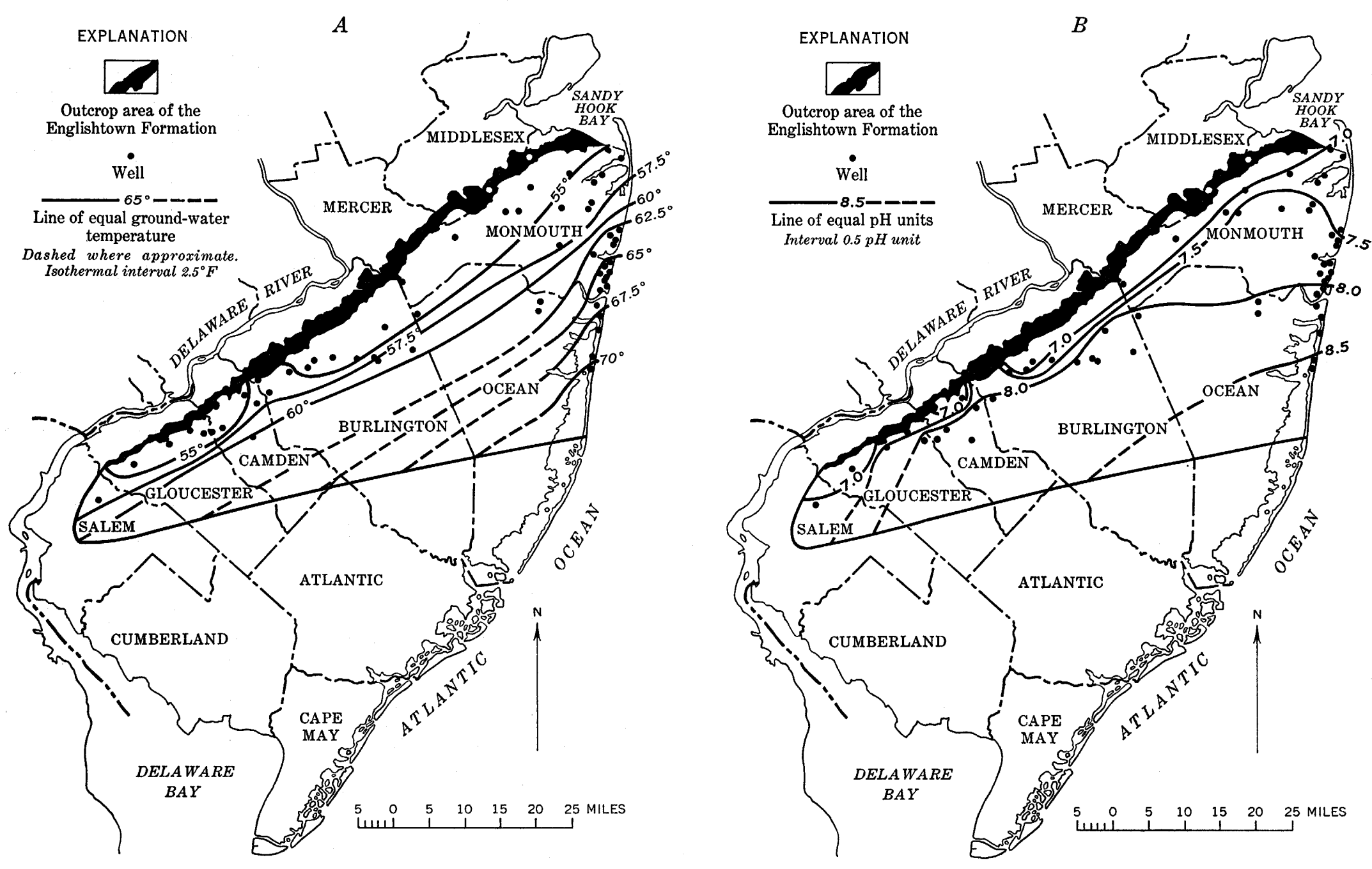

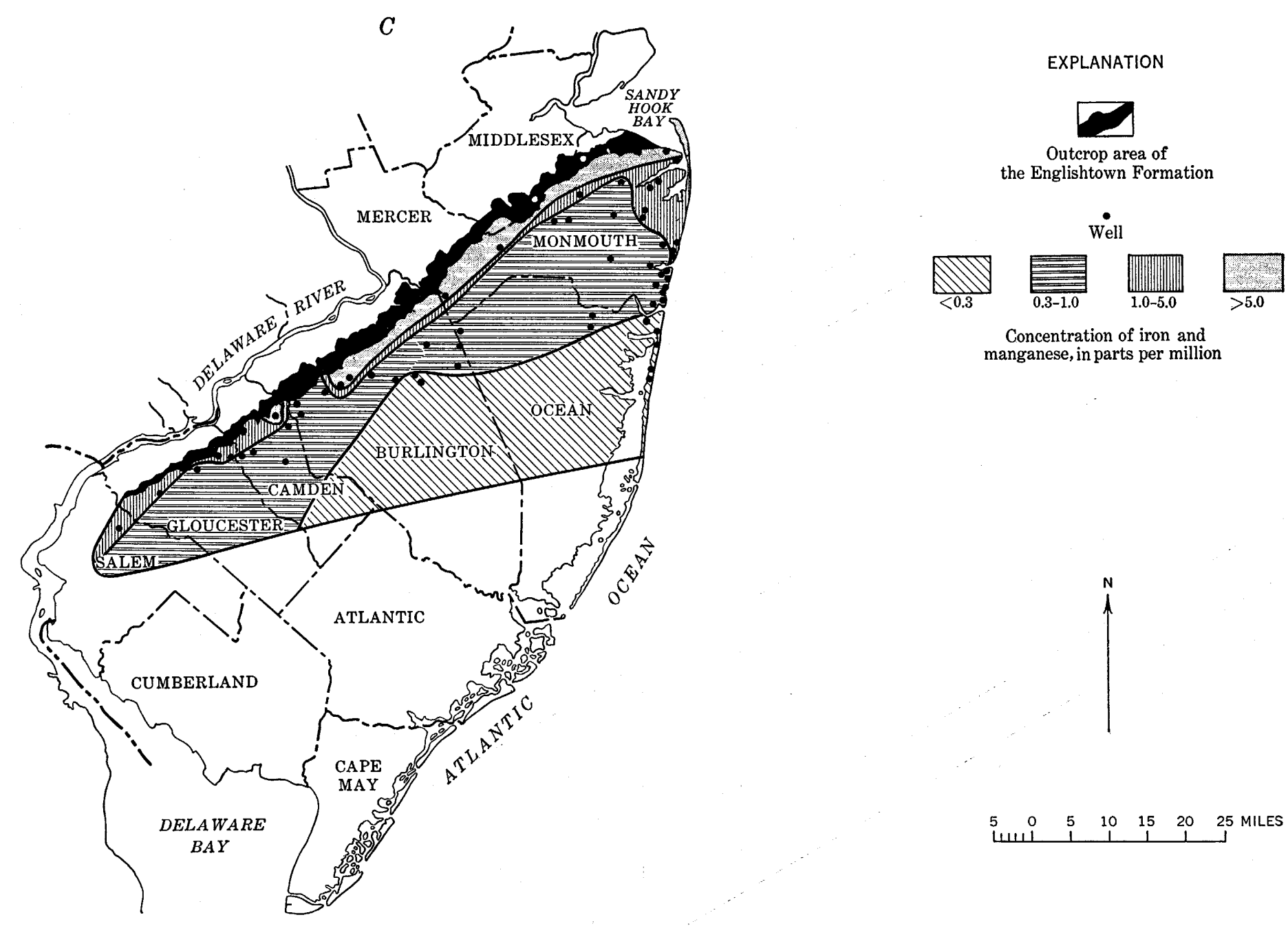

Fiadre 5.-Distribution of $(A)$ temperature, $(B) \mathrm{pH}$, and $(C)$ iron and manganese in ground water in the Englishtown Formation. In figure $B$, the line of equal $\mathrm{pH}$ units is dashed where approximate. 


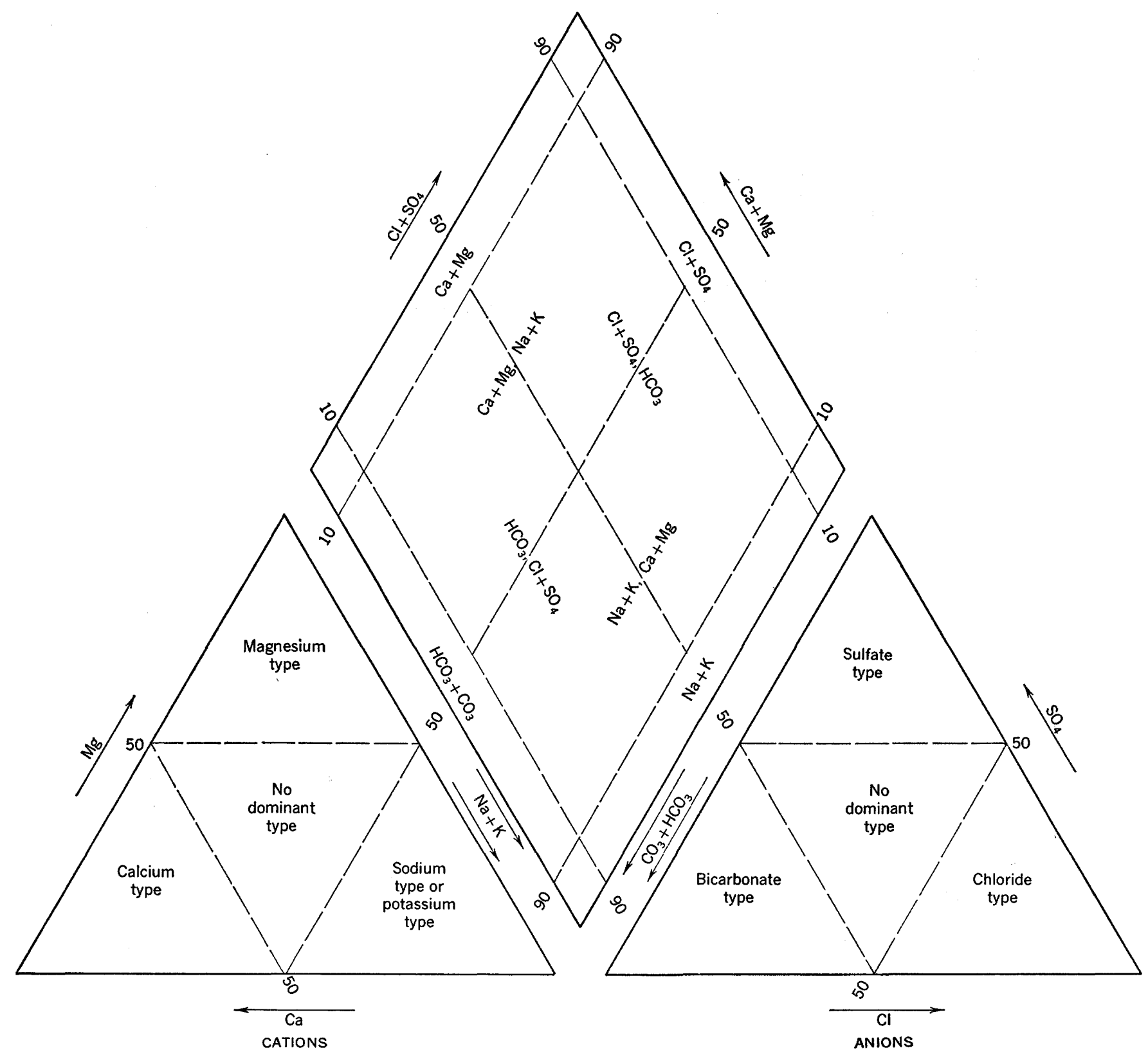

PERCENTAGE REACTING VALUES

FIGURf 6.-Hydrochemical facies, in percentage of equivalents per million. Modified from Morgan and Winner (1962, p. B121).

The anion hydrochemical facies distribution shown in figure $7 \mathrm{~A}$ indicates that the $\mathrm{HCO}_{3}+\mathrm{CO}_{3}$ facies and the $\mathrm{HCO}_{3}, \mathrm{Cl}+\mathrm{SO}_{4}$ facies are predominant. The bicarbonate ions originate directly from the atmosphere, from the solution of calcium carbonate by ground water made slightly acidic by dissolving carbon dioxide gas from the atmosphere, from the generation of carbon dioxide from decaying carbonaceous material, and from reactions occurring in the weathering profile. The sulfate and chloride ions do not occur in large amounts in the water, and the presence of the $\mathrm{Cl}+\mathrm{SO}_{4}$ facies and the $\mathrm{Cl}+\mathrm{SO}_{4}, \mathrm{HCO}_{3}$ facies in the outcrop area is due to lack of calcareous material, to presence of iron sulfide minerals in which the sulfide is oxidized to sulfate, and to some contamination by fertilizer, sewage, industrial wastes, and salts applied to highways. No saline waters are present at depth in the aquifer to produce the high $\mathrm{Cl}+\mathrm{SO}_{4}$ facies common in other Coastal Plain aquifers.

BICARBONATE AND CARBONATY

The areal distribution of the bicarbonate content of the ground water in the Englishtown Formation shown in figure $8 A$ is similar to that of the calcium content of the water (shown in fig. 9A). Except for the area 


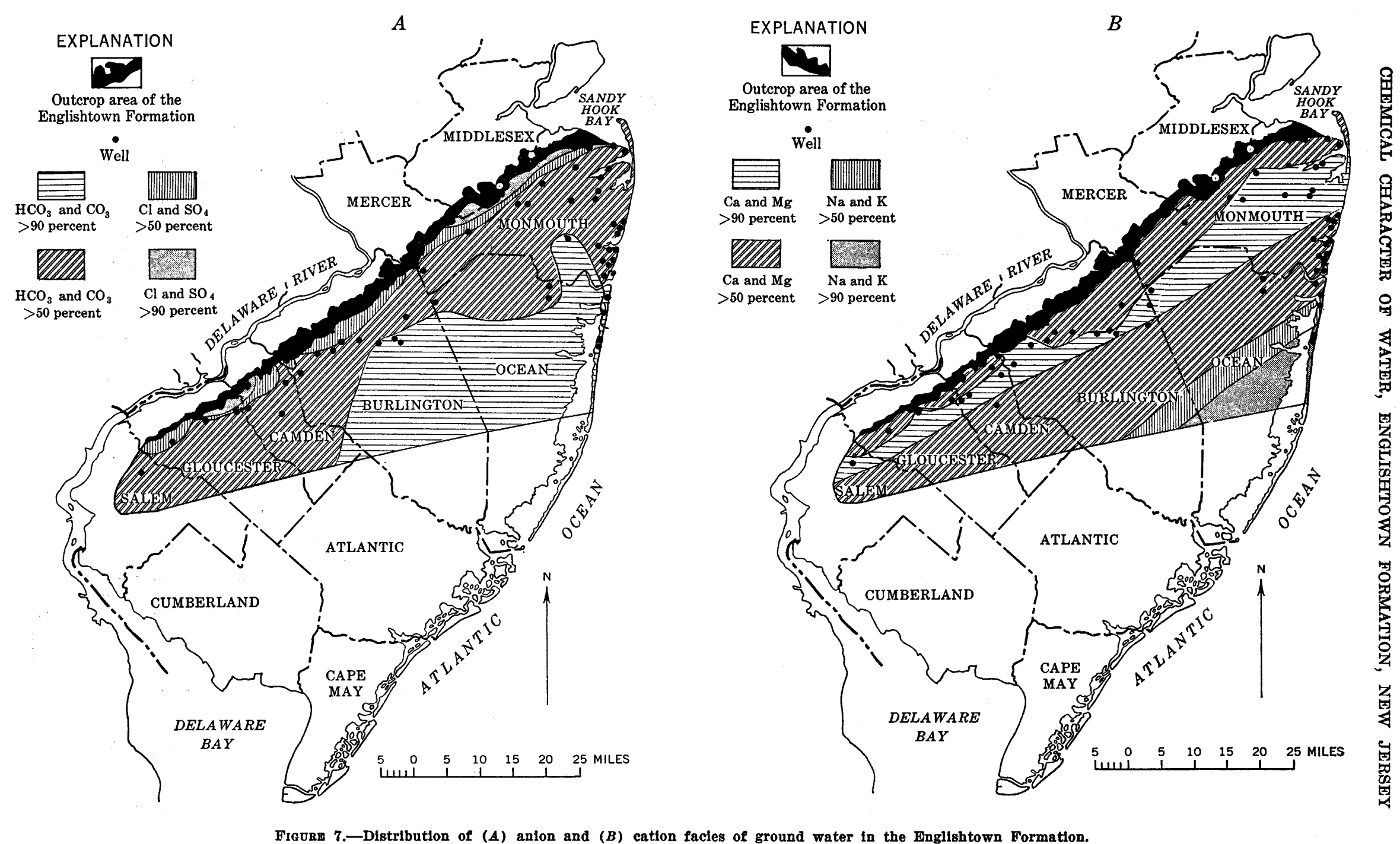



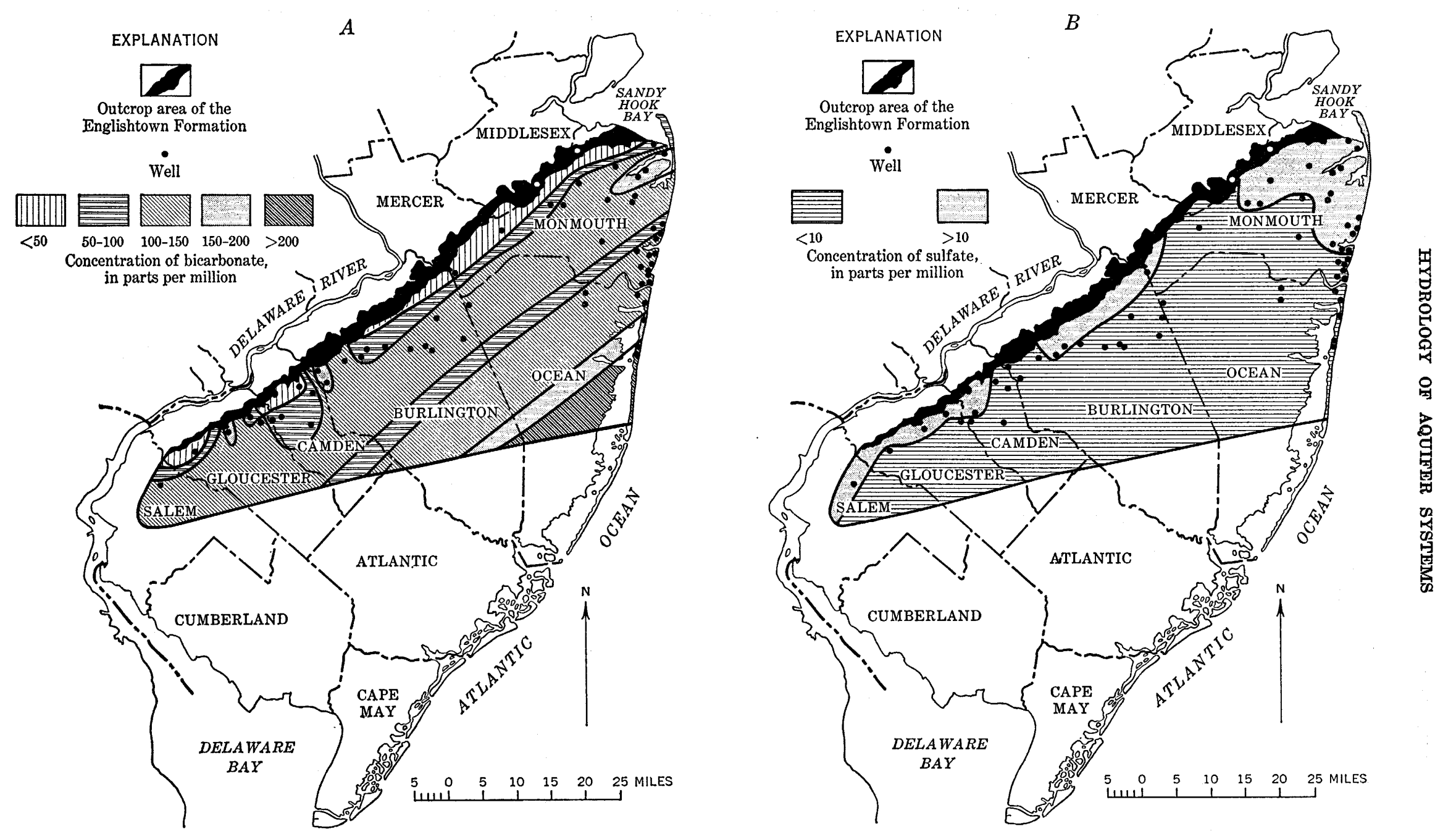

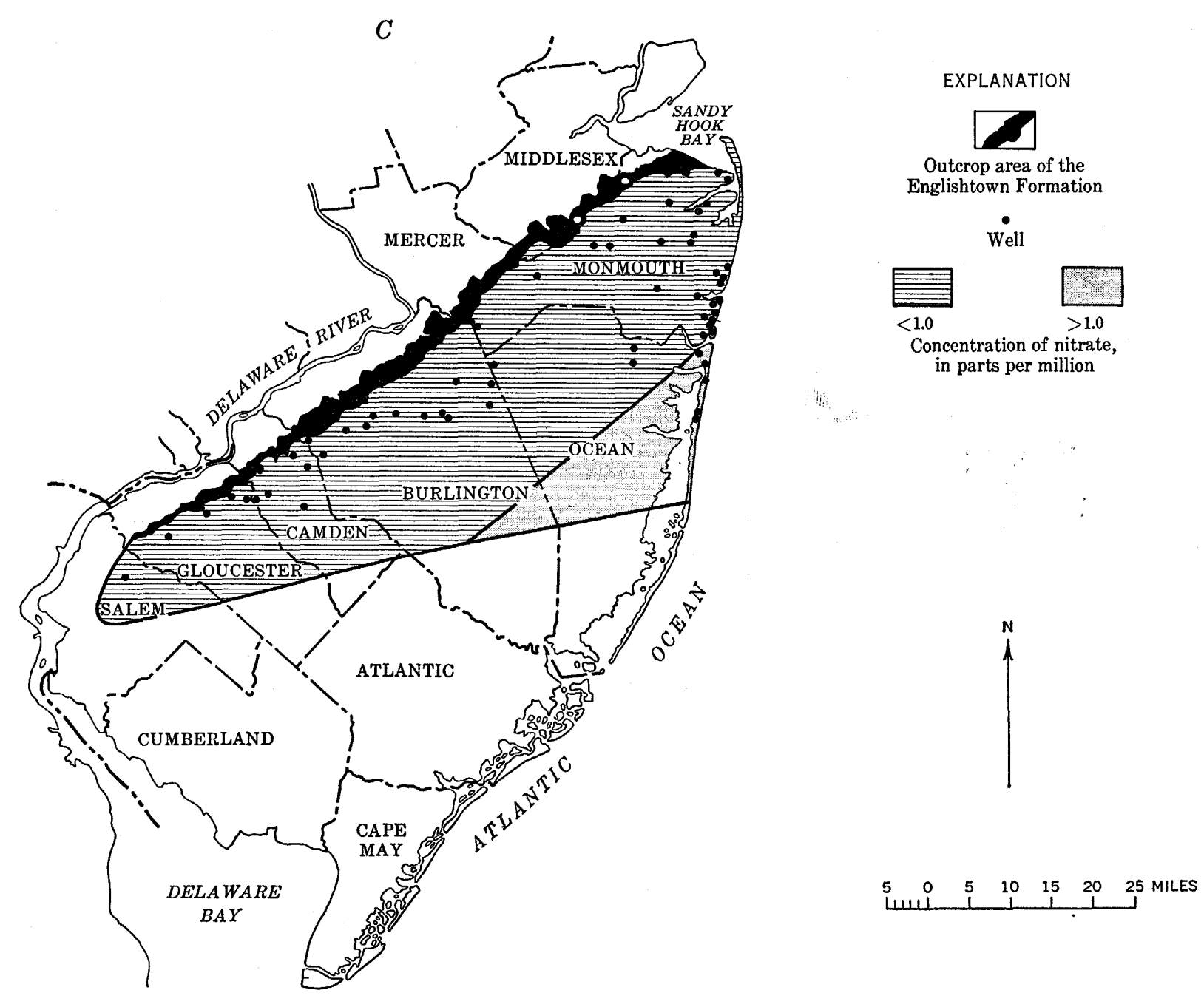

FIGURE 8.-Distribution of anions in ground water in the Englishtown Formation. $A$, bicarbonate; $B$, sulfate; $C$, nitrate. 
along the coast in Ocean County, the water has either a high or a low content of both calcium and bicarbonate. In coastal Ocean County, the water has a high sodium and bicarbonate content. The similarities in calcium and bicarbonate indicate that the bicarbonate in the water is due largely to solution of calcium carbonate. In the areas of the piezometric highs, the sediments making up the Englishtown Formation contain little or no calcareous material, but the water in these sediments has a high calcium and bicarbonate content. The water entering the Englishtown in these areas from the overlying Marshalltown Formation has a high calcium and bicarbonate content similar to that occurring in the Englishtown. Thus, the origin of the calcium and bicarbonate in the water in this area is solution of calcareous material by waters rich in carbon dioxide derived from the atmosphere and from soil in the overlying formations whose materials include abundant calcareous shell fragments.

The decrease in concentration of calcium and bicarbonate both updip and downdip from the areas of the piezometric highs either results from infiltration of water that contains little calcium and bicarbonate in solution or results from adsorption by lignite. Margaret Foster (1950, p. 41-46) showed experimentally that calcium bicarbonate water in contact with lignite in the absence of calcium carbonate and ion-exchange material loses calcium and bicarbonate, and she attributed the loss to adsorption by lignite. Direct precipitation of calcium carbonate over wide areas as an explanation for the loss of the calcium and bicarbonate is untenable. Calculations, made by the procedure outlined by Back (1961a), of calcium carbonate saturation for the water from wells for which field analyses of $\mathrm{pH}$ and bicarbonate were available indicated that the water in areas where a decrease in calcium and bicarbonate occurs is undersaturated. Precipitation of calcium carbonate may occur in small areas in Burlington, Camden, and Gloucester Counties, inasmuch as water from several wells $(58,61,64,66,68$, and 81$)$ indicated the possibility of supersaturated conditions with respect to calcium carbonate. However, further decreases in the calcium and bicarbonate content occur both updip and downdip along flowlines between wells where the water is undersaturated with respect to calcium carbonate; a mechanism other than direct precipitation of calcium carbonate is therefore required. All the water from wells in Monmouth County and interior Ocean County for which calculations of calcium carbonate saturation were made-that is, all the water from wells for which field determinations of $\mathrm{pH}$ and bicarbonate were available-appears to be undersaturated with respect to calcium carbonate.
In the area updip from the piezometric highs, especially in the outcrop, the decrease in calcium and bicarbonate is probably due to infiltration of water that contains little of these two constituents. The water in this area has had a shorter "residence time" in the Coastal Plain sediments and reflects a loss in relative amounts of almost every constituent except iron and sulfate. The decrease in calcium and bicarbonate downdip probably is due to the adsorption by lignite of calcium carbonate, because the water does not change in character except for these two constituents.

The increase in bicarbonate in coastal Ocean County occurs where the Englishtown sediments contain calcareous shell fragments (particularly Foraminifera), ion-exchange material (especially montmorillonite), and lignitic material. Foster $(1950$, p. 33-48) has shown that where a water-bearing formation contains these three materials, dynamochemical processes result in the generation of water rich in sodium and bicarbonate. In such a process, carbon dioxide is generated by alteration of carbonaceous material in the sediments; the water then dissolves calcium carbonate, the calcium thus taken into solution being replaced by sodium through the action of ion-exchange materials; the end result of these reactions is an increase in the sodium bicarbonate content of the waters (Foster, p. 41). Calculations of the degree of calcium carbonate saturation of water from wells $48,52,54,56$, and 57 all indicated an approximate equilibrium condition of the water with respect to calcium carbonate, which is the condition required for the above processes to be operative.

\section{SULFATE}

The sulfate content of the ground water in the Englishtown Formation is fairly low (fig. $8 B$ ). The sulfate content of the water in the outcrop area and immediately downdip from the outcrop area is generally higher than that in other areas, except for the area along the Camden and Burlington County boundary line and an area in southwestern Monmouth County. The sulfate and iron contents of the water seem to be related. Where the iron content is greater than $1 \mathrm{ppm}$, the sulfate is generally greater than $10 \mathrm{ppm}$, and where the iron content is less than $1 \mathrm{ppm}$, the sulfate is less than $10 \mathrm{ppm}$. The origin of the sulfate is iron sulfide minerals; the sulfide is oxidized to sulfate and the water therefore has high concentrations of both iron and sulfate. The sulfate content decreases downdip, a major decrease occurring along the coast in Ocean County. The decrease may be caused by the reduction of sulfate or by the precipitation of iron sulfide or calcium sulfate.

\section{NITRATE}

The nitrate content in the ground water in the Eng- 
lishtown Formation is uniformly low (fig. $8 C$ ). In general, the nitrate content of the water is less than $1.0 \mathrm{ppm}$, except along the shore in Ocean County where the high value is $3.1 \mathrm{ppm}$. The slight increase in Ocean County is probably the result of decomposition of lignite or other organic material. A few shallow wells yielded water containing high concentrations of nitrates (as much as $80 \mathrm{ppm}$ ) accompanied by low concentrations of bicarbonates, but the nitrate content of the water in these isolated areas could be traced to some source of contamination, such as fertilizer or sewage.

\section{CHLORIDE AND FLUORIDE}

The chloride content of the ground water in the Englishtown Formation is uniformly low, and it does not exhibit any particular spatial pattern. The source of the chloride is probably entirely atmospheric precipitation. Many wells yield water with a chloride content of less than $5 \mathrm{ppm}$, and only a few wells yield water with a chloride content of more than $10 \mathrm{ppm}$. These few wells show some degree of contamination. As far as known, the Englishtown does not contain saline water at depth. Perhaps the area adjacent to Sandy Hook Bay and the Atlantic Ocean will be subjected to salt-water encroachment in the future, but no part of the aquifer being developed at the present time (1963) contains even a trace of saline water.

The fluoride content of the ground water from the Englishtown Formation is uniformly low, that is, less than $0.8 \mathrm{ppm}$, and exhibits no particular spatial distribution.

\section{CATION HYDROCHEMICAT FACIES}

The following terms are used to designate particular cation facies adapted from those used by Back (1961b, p. D381): The calcium-magnesium $(\mathrm{Ca}+\mathrm{Mg})$ facies occurs where calcium and magensium ions compose 90 percent or more of the total cations (on the basis of equivalents per million, not parts per million); the calcium-sodium $(\mathrm{Ca}+\mathrm{Mg}, \mathrm{Na}+\mathrm{K})$ facies exists where the calcium and magnesium content exceeds 50 percent but is less than 90 percent of the total cations, and the sodium and potassium content exceeds 10 percent but is less than 50 percent; the sodium-calcium $(\mathrm{Na}+\mathrm{K}, \mathrm{Ca}+$ Mg) facies designates the chemical character of water in which the content of the sodium and potassium ions exceeds 50 percent but is less than 90 percent of the total cations; the sodium-potassium $(\mathrm{Na}+\mathrm{K})$ facies occurs where the sodium and potassium ions exceed 90 percent and the calcium and magnesium equal less than 10 percent. In the Englishtown Formation the potassium and magnesium content of the water does not change significantly, but it is considered here for uniformity with the concepts of the hydrochemical facies used by Back for the Atlantic Coastal Plain; hence, the various cation hydrochemical facies are determined primarily by the ratio of calcium to sodium in the water. The potassium and magnesium ions in the ground water probably originate from atmospheric precipitation and from solution of silicate minerals primarily in the weathering profile at the ground surface.

The distribution of the cation hydrochemical facies is shown in figure 7B. The $\mathrm{Ca}+\mathbf{M g}$ facies results from solution of calcareous materials in the overlying formations by ground water which enters the Englishtown Formation in the areas of the piezometric highs (fig. $3 \mathrm{D})$. In the outcrop area, which presumably has been functioning as a discharge area for a long period of time, the material has been subjected to acid water, and whatever calcium carbonate material may have been present has been leached, in addition to being deficient in calcareous material since its deposition; therefore, in this area a $\mathrm{Ca}+\mathrm{Mg}, \mathrm{Na}+\mathrm{K}$ facies is present. At depth the calcium is being removed from the water by an ion-exchange process and the $\mathrm{Na}+\mathrm{K}$ facies results. The ion-exchange process is stoichiometric. The water analyses indicate that additional calcium, resulting from solution of calcareous fossils in the formation, enters the water at depth, participates in an ion-exchange reaction, and increases the proportion of sodium to calcium in the water. The presence of sodium montmorillonite in the subsurface deposits of the Englishtown is speculative, but it is indicated by the water chemistry

The decrease in calcium and the increase in sodium content of the water could be explained by the solution of sodium silicate minerals. This reaction would increase the sodium content of the ground water and raise the $\mathrm{pH}$, an accompanying precipitation of calcium carbonate causing the decrease in calcium content of the water. However, the bicarbonate content of the water in this area increases and this mechanism offers no source of additional carbonate ions.

The zone separating the $\mathrm{Ca}+\mathrm{Mg}, \mathrm{Na}+\mathrm{K}$ facies from the $\mathrm{Na}+\mathrm{K}, \mathrm{Ca}+\mathrm{Mg}$ facies along the coast in Ocean County is considered to be an "ion-exchange front." This front is moving slowly east-southeastward at an unknown rate in the direction of the movement of the water in the formation. The present alinement and position of the front is governed more by the original piezometric surface, which existed prior to pumping from the Englishtown Formation, than by the present piezometric surface.

\section{CALCTUM AND MAGNESTUM}

The calcium content of the ground water exhibits the same areal pattern as the bicarbonate, being high in the recharge area and low in the outcrop area (fig. 9A). 

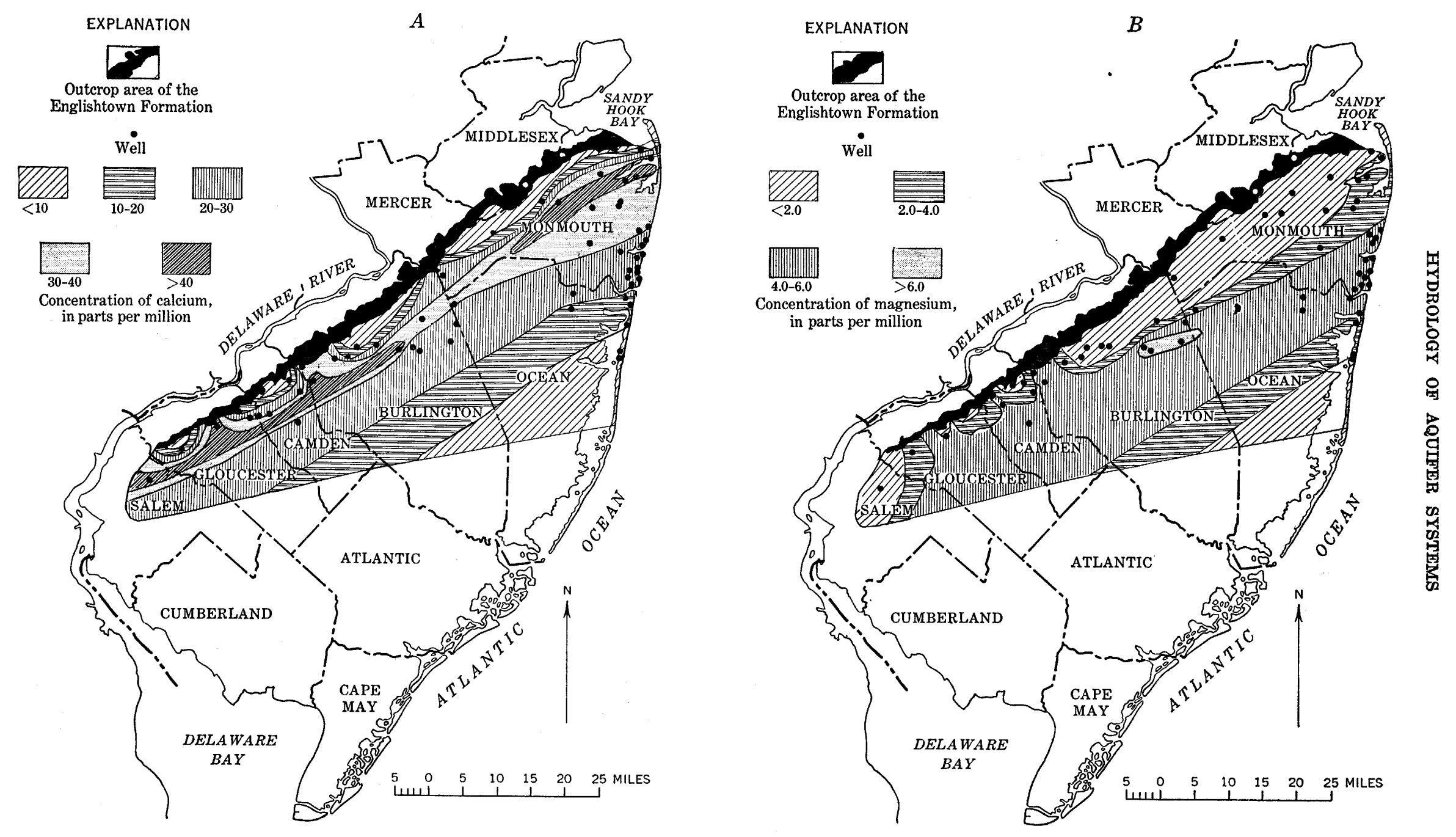


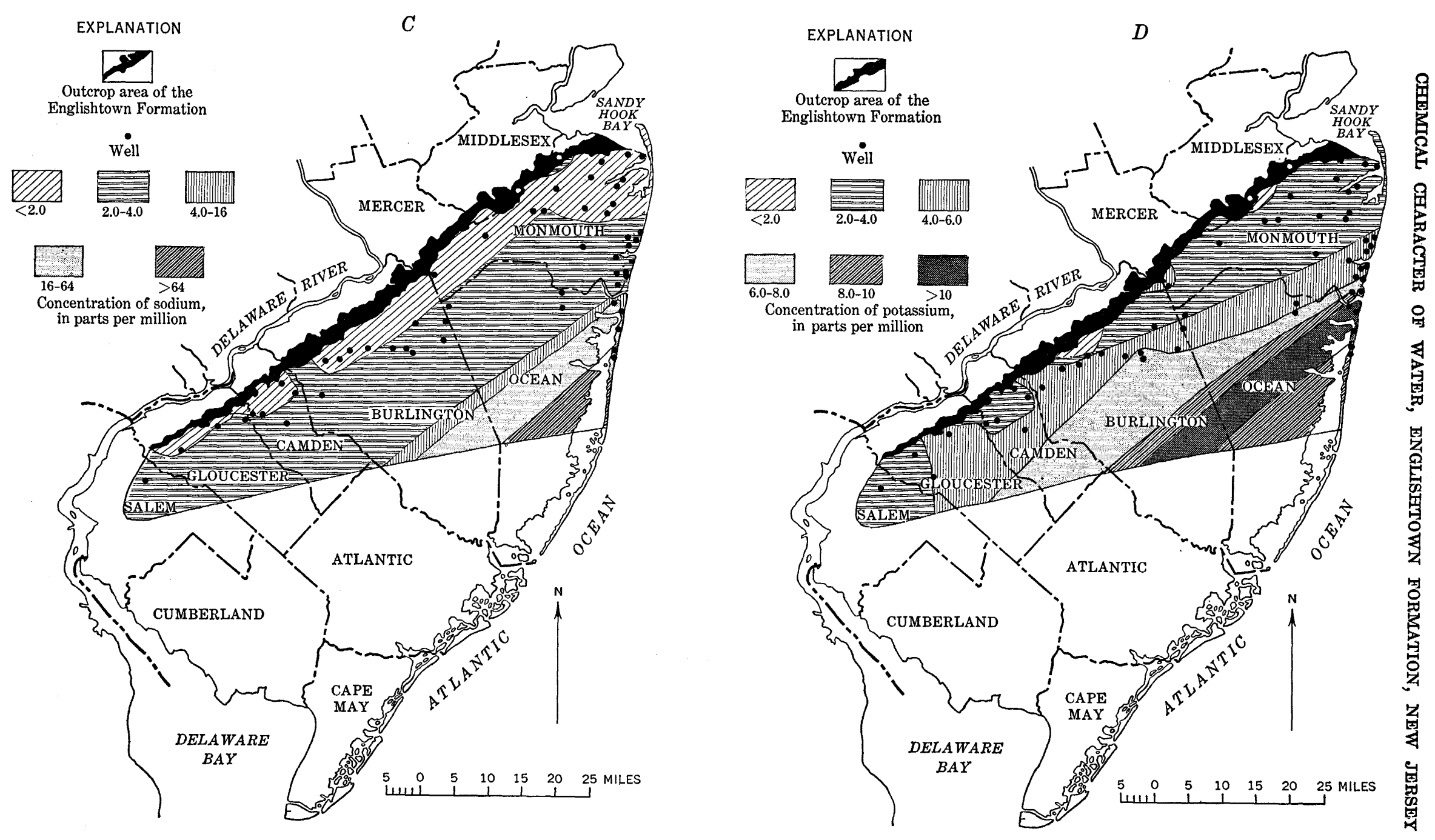

FIGURE 9.-Distribution of cations in ground water in the Englishtown Formation. $A$, calcium; $B$, magnesium; $C$, sodium; $D$, potassium. 
At depth the calcium content is again low as the result of ion exchange.

The magnesium content of the ground water increases downdip from the outcrop area for about 20 miles, then decreases slightly (fig. $9 B$ ). The decrease may be due to the precipitation of magnesium as magnesium carbonate or to ion-exchange reaction similar to that involving calcium and sodium. The magnesium content of the ground water in the outcrop area is variable.

\section{SODIUM AND POTASSIUM}

The sodium content of the ground water is uniformly low, less than $5.0 \mathrm{ppm}$, except along the shore in Ocean County (fig. $9 C$ ). In general, it increases gradually for a distance of about 22 miles downdip from the outcrop area, then increases greatly.

The potassium content of the ground water is also uniformly low, less than $6.0 \mathrm{ppm}$, except along the shore in Ocean County (fig. 9D). It increases slowly downdip for a distance of about 22 miles, then remains constant for about 5 miles, and finally decreases slightly. Perhaps the potassium is involved in an ion-exchange process.

\section{CONCLUSIONS}

Areal mapping of water-quality characteristics has been used to demonstrate some relationships between chemical content of the ground water, lithology, topography, and flow patterns in the Atlantic Coastal Plain of New Jersey. It has been demonstrated that the chemistry of the ground water in the Englishtown Formation is dependent upon the hydrology and physical framework of geology and topography. In its response to the physical environment it may give clues to otherwise unnoticed relations between geology, hydrology, and water chemistry.

The areal distribution of the chemical characteristics of ground water may lend support to, or even suggest, geologic or hydrologic data that would not be obtainable by conventional methods of study or that would be prohibitively expensive to obtain by other methods. The mapping of water-quality data (hydrochemical maps) is particularly important in evaluating an aquifer satisfactorily, and could be equally useful in regional geologic studies concerned with continuity of units or mineralogic differences and similarities.

The chemical characteristics mapped in this study were chosen because they were responsive to the particular physical environment of the New Jersey Coastal Plain. In other areas, different ratios or characteristics of the water chemistry may be more useful in determining which constituents are responsive to the environment. In this study, only those characteristics of water normally determined in a routine analysis were used to produce the hydrochemical maps. This procedure demonstrated that many analyses now available for other aquifers could be used in similar studies. However, trace elements or other minor constituents of the water may locally be the most useful in pointing out relationships.

\section{SELECTED REFERENCES}

American Commission on Stratigraphic Nomenclature, 1961, Code of stratigraphic nomenclature: Am. Assoc. Petroleum Geologists Bull., v. 45, no. 5, p. 645-665.

Back, William, 1960, Origin of hydrochemical facies of ground water in the Atlantic Coastal Plain : Internat. Geol. Cong., 21st, Copenhagen, 1960, Proc., pt. 1, p. 87-95.

1961a, Calcium carbonate saturation in ground water, from routine analyses: U.S. Geol. Survey Water-Supply Paper 1535-D, 14 p.

1961b, Techniques for mapping of hydrochemical facies: U.S. Geol. Survey Prof. Paper 424-D, art. 423, p. D380 D382.

Barksdale, H. C., Greenman, D. W., Lang, S. M., Hilton, G. S., and Outlaw, D. E., 1958, Ground-water resources in the tristate region adjacent to the Lower Delaware River: New Jersey Div. Water Policy and Supply Spec. Rept. 13, 190 p.

Barksdale, H. C., Johnson, M. E., Schaefer, E. J., Baker, R. C., and DeBuchananne, G. D., 1943, The ground-water supplies of Middlesex County, New Jersey : New Jersey State Water Policy Comm. Spec. Rept. 8, 160 p.

Barksdale, H. C., Sundstrom, R. W., and Brunstein, M. S., 1936, Supplementary report of the ground-water supplies of the Atlantic City region: New Jersey State Water Policy Comm. Spec. Rept. 6, 139 p.

Clark, W. B., Bagg, R. M., and Shattuck, G. B., 1898, Report upon the Upper Cretaceous Formations: New Jersey Geol. Survey Ann. Rept. State Geologist for 1897, p. 161-210.

Cook, G. H., 1868, Geology of New Jersey : Newark, N.J., New Jersey Geol. Survey, $900 \mathrm{p}$.

Donski, Ellis, 1963, Records of wells and ground-water quality in Camden County, N.J.: New Jersey Div. Water Policy and Supply Water Resources Circ. 10, 70 p.

Foster, M. D., 1950, The origin of high sodium bicarbonate waters in the Atlantic and Gulf Coastal Plains: Geochim. et Cosmochim. Acta, v. 1, p. 33-48.

Gill, H. E., 1962, Ground-water resources of Cape May County, New Jersey: New Jersey Div. Water Policy and Supply Spec. Rept. 18, 171 p.

Gill, H. E., Seaber, P. R., Vecchioli, John, and Anderson, H. R., 1963, Evaluation of geologic and hydrologic data from the test-drilling program at Island Beach State Park, New Jersey : New Jersey Div. Water Policy and Supply Water Resources Circ. 12, 25 p.

Groot, J. J., and Glass, H. D., 1960, Some aspects of the mineralogy of the Atlantic Coastal Plain, in Clay Conf., 7th, Washington, D.C., 1958: New York, Pergamon Press, p. 271-284,

Hardt, W. F., 1963, Public water supplies in Gloucester County, New Jersey: New Jersey Div. Water Policy and Supply Water Resources Circ. 9, 55 p.

Jablonski, L. A., 1959, Records of wells and ground-water quality in Monmouth County, New Jersey: New Jersey Div. Water Policy and Supply Water Resources Circ. 2, 47 p. 
Jablonski, L. A., 1960, Factual data for public-supply wells and selected irrigation wells in Monmouth County, New Jersey : New Jersey Div. Water Policy and Supply Water Resources Circ. 4, 28 p.

Johnson, M. E., and Richards, H. G., 1952, Stratigraphy of the Coastal Plain of New Jersey: Am. Assoc. Petroleum Geologists Bull., v. 36, no. 11, p. 2150-2160.

Kümmel, H. B., 1908, Administrative report, 1907 : New Jersey Geol. Survey Ann. Rept. State Geologist, p. 1-19.

Minard, J. P., and Owens, J. P., 1962, Pre-Quaternary geology of the New Egypt quadrangle, New Jersey : U.S. Geol. Survey Geol. Quad. Map GQ-161.

Morgan, C. O., and Winner, M. D., Jr., 1962, Hydrochemical facies in the " 400 -foot" and "600-foot" sands of the Baton Rouge area, Louisiana: U.S. Geol. Survey Prof. Paper 450-B, art. 50, p. B120-B123.

Owens, J. P., and Minard, J. P., 1960, The geology of the northcentral part of the New Jersey Coastal Plain: Baltimore, The Johns Hopkins Univ., Studies in Geology, no. 18, 45 p.

1962, Pre-Quaternary geology of the Columbus quadrangle, New Jersey: U.S. Geol. Survey Geol. Quad. Map GQ-160.

Owens, J. P., Minard, J. P., and Blackmon, P. D., 1961, Distribution of clay-sized sediments in the Coastal Plain formations near Trenton, New Jersey: U.S. Geol. Survey Prof. Paper 424-C, art. 263, p. C317-C319.

Rainwater, F. H., and Thatcher, L. L., 1960, Methods of collection and analysis of water samples: U.S. Geol. Survey Water-Supply Paper 1454, 301 p.

Reed, J. C., 1960, Heavy minerals of the Englishtown (Cretaceous) Formation of New Jersey : Pennsylvania Acad. Sci. Proc., v. 34, p. 147-154.

Richards, H. G., 1945, Subsurface stratigraphy of the Atlantic Coastal Plain between New Jersey and Georgia : Am. Assoc. Petroleum Geologists Bull., v. 29, no. 7, p. 885-955.

-1956, Geology of the Delaware Valley : Philadelphia Mineralog. Soc. Pennsylvania, 106 p.

- ed., 1958, The Cretaceous fossils of New Jersey: New Jersey Geol. Survey Paleontology Ser., pt. 1, 266 p.

Ries, Heinrich, Kümmel, H. B., and Knapp, G. N., 1904, The clays and clay industry of New Jersey: New Jersey Geol. Survey Final Rept. Ser. State Geologist, v. 6, p. 117-209.
Roberson, C. E., Feth, J. H., Seaber, P. R., and Anderson, Peter, 1963, Differences between field and laboratory determinations of $\mathrm{pH}$, alkalinity, and specific conductance of natural water: U.S. Geol. Survey Prof. Paper 475-C, art. 115, p. C212-C215.

Rogers, H. D., 1836, Report on the Geological Survey of the State of New Jersey: Trenton, New Jersey Geol. Survey, $188 \mathrm{p}$.

- 1840, Description of the geology of the State of New Jersey, being a final report: Philadelphia, New Jersey Geol. Survey, 301 p.

Rush, F. E., 1962, Records of wells and ground-water quality in Burlington County, New Jersey: New Jersey Div. Water Policy and Supply Water Resources Circ. 7, 104 p.

Salisbury, R. D., 1899, Surface geology : New Jersey Geol. Survey Ann. Rept. State Geologist, for 1898, p. 1-41.

Salisbury, R. D., and Knapp, G. N., 1917, The Quaternary formations of southern New Jersey : New Jersey Geol. Survey Final Rept. Ser. State Geologist, v. 8, 218 p.

Seaber, P. R., 1960, Hydrochemical facies and ground-water flow patterns in the Englishtown Sand in the Coastal Plain of New Jersey [abs.] : Geol. Soc. America Bull., v. 71, no. 12, p. 1971.

1962, Cation hydrochemical facies of ground water in the Englishtown Formation, New Jersey: U.S. Geol. Survey Prof. Paper 450-B, art. 51, p. B124-B126.

- 1963, Chloride concentrations of water from wells in the Atlantic Coastal Plain of New Jersey, 1923-61 : New Jersey Div. Water Policy and Supply Spec. Rept. 22, 250 p.

Seaber, P. R., and Vecchioli, John, 1963, Stratigraphic section at Island Beach State Park, New Jersey : U.S. Geol. Survey Prof. Paper 475-B, art. 26, p. B102-B105.

Thompson, D. G., 1930, Ground-water supplies in the vicinity of Asbury Park, New Jersey: New Jersey Dept. Conserv. Econ. Devel. Bull. 35, 50 p.

U.S. Geological Survey, 1961, Tectonic map of the United States : Washington, U.S. Government Printing Office.

Vecchioli, John, and Palmer, M. M., 1963, Ground-water resources of Mercer County, New Jersey: New Jersey Div. Water Policy and Supply Spec. Rept. 19, 71 p.

Weller, Stuart, 1907, A report on the Cretaceous paleontology of New Jersey, based on the stratigraphic studies of George N. Knapp: New Jersey Geol. Survey Paleontology Ser., v. 4, $1107 \mathrm{p}$. 
